\title{
The Wooden Roof Framing Elements, Furniture and Furnishing of the Etruscan Domus of the Dolia of Vetulonia (Southern Tuscany, Italy)
}

\author{
Ginevra Coradeschi ${ }^{1} \mathbb{D}$, Massimo Beltrame $^{1} \mathbb{D}$, Simona Rafanelli ${ }^{2}$, Costanza Quaratesi ${ }^{2}$, Laura Sadori ${ }^{3} \mathbb{D}$ \\ and Cristina Barrocas Dias ${ }^{1,4, *}$
}

check for

updates

Citation: Coradeschi, G.; Beltrame,

M.; Rafanelli, S.; Quaratesi, C.; Sadori,

L.; Barrocas Dias, C. The Wooden

Roof Framing Elements, Furniture

and Furnishing of the Etruscan

Domus of the Dolia of Vetulonia

(Southern Tuscany, Italy). Heritage

2021, 4, 1938-1961. https://doi.org/

$10.3390 /$ heritage 4030110

Academic Editor: Diego Tamburini

Received: 21 July 2021

Accepted: 17 August 2021

Published: 20 August 2021

Publisher's Note: MDPI stays neutral with regard to jurisdictional claims in published maps and institutional affiliations.

Copyright: (C) 2021 by the authors. Licensee MDPI, Basel, Switzerland. This article is an open access article distributed under the terms and conditions of the Creative Commons Attribution (CC BY) license (https:/ / creativecommons.org/licenses/by/ $4.0 /)$.
1 HERCULES Laboratory, University of Évora, Largo do Marquês de Marialva, n.8, 7000-804 Évora, Portugal; ginevrac@uevora.pt (G.C.); massimo@uevora.pt (M.B.)

2 Isidoro Falchi Civic Archaeological Museum, Piazza Vetluna, 58043 Vetulonia, Italy; simrafan@gmail.com (S.R.); costanza.quaratesi@gmail.com (C.Q.)

3 Department of Environmental Biology, Sapienza University of Rome, Piazza Aldo Moro, n.5, 00185 Rome, Italy; laura.sadori@uniroma1.it

4 Chemistry Department, School of Sciences and Technology, University of Évora, Rua Romão Ramalho, n.59, 7000-671 Évora, Portugal

* Correspondence: cmbd@uevora.pt

\begin{abstract}
The Etruscan Domus of the Dolia remained hidden until 2009, when archaeological excavations began in the Etruscan-Roman district of Vetulonia (Southern Tuscany). Based on the classification of the archaeological materials recovered, the destruction of the Domus and the Etruscan city of Vetulonia was traced back to the 1st century BC. The highly various and precious materials recovered inside the Domus revealed the richness of the building and its inhabitants. With this study, we present the anthracological analyses from the Domus of the Dolia. Wood charcoals were recovered from different house rooms, which had different functions based on the archaeological evidence. The tree species employed for the construction of the roof of the building were deciduous and semi-deciduous oak wood (Quercus sect. robur, Quercus sect. cerris) and silver fir wood (Abies cf. alba). Evergreen oak wood (Quercus sect. suber), boxwood (Buxus sempervirens), beech wood (Fagus cf. sylvatica), maple wood (Acer sp.) and cherry wood (Prunus cf. avium) were adopted for the furniture and furnishings of the house. Moreover, wood charcoal fragments of fruit trees belonging to the family of Rosaceae were identified, documenting a possible garden inside the court of the house. The study shows the use of the local tree species primarily. The silver fir wood and beech wood were likely sourced from the nearby (roughly $60 \mathrm{~km}$ ) Mount Amiata.
\end{abstract}

Keywords: archaeobotany; etruscan archaeology; Southern Tuscany; charcoal; wood exploitation

\section{Introduction}

The Etruscans, known as Tyrsenoi or Thyrrenoi by the ancient Greeks, flourished in central Italy between the 9 th and the 1st century BC. They mainly settled and ruled in central Italy (in part of the present-day territory of the Tuscany, Lazio and Umbria regions), with important presences in Campania, in a large part of the Po valley (Emilia Romagna, Lombardy, Veneto) and on Corsica Island. Etruscans were one of the most important civilizations of ancient Italy, and the funerary equipment recovered on several monumental burial mounds is widely known, being evidence of the degree of their civilization. Organized through a confederation of 12 city states (Dodecapoli), they are quite famous for their deep metallurgical skills, for the ability of their artisans in gold processing, for their capability of trading, and for their cult of the deaths. Moreover, they were also skilled sailors and traders, having contact with the most important civilizations of the Mediterranean Area. From the 3rd century BC, the Etruscan civilization was slowly adsorbed by the Roman Empire (three of the legendary kings at the dawn of ancient Rome were Etruscans) [1-4]. 
Even if much is known about their cult of death, little is known, on the contrary, on Etruscan daily life and settlements [5]. In particular, the exploitation of natural resources for construction purposes has rarely been addressed [6,7], and few data are available regarding the exploitation and selection of wood [8-13].

Different scholars ascribed to Etruscans, through pollen analysis, the responsibility of forest clearance that heavily altered the surrounding environment [14-17], but systematic archaeobotanical studies from Etruscan settlements are occasional, and a clear connection between the opening of forests and the wood used for building, cooking and smelting has never been established.

Given the rarity of this type of study, the analysis of the charred woods of the Domus of the Dolia proves to be important, in particular for the deepening of knowledge about the Etruscan world of the living, which still today remains largely unknown.

The discovery of the Domus of the Dolia, located in the ancient town of Vetulonia (Castiglione della Pescaia, Southern Tuscany, Italy), and the study of the materials retrieved, made it possible to create an accurate reconstruction of the entire Etruscan house, and to describe the life and the activities of the wealthy inhabitants of the Domus between the 3 rd and the 1st century BC $[18,19]$. Moreover, the extraordinary nature of the architectural data unearthed by the archaeological excavation allowed for the acquisition of information concerning the city of Vetulonia in the last centuries of its Etruscan history. Among the materials retrieved from the excavation of the Domus, there were bricks, mortars, roof tiles, different ceramic wares, votive bronze statues, coins, nails, and numerous charred woods, with these being the last the object of this study. The analysis of wood charcoals belonging to several structural and furnishing elements coming from different rooms of the Domus of the Dolia represents the first study regarding the choice and the use of wood by the Etruscans of Vetulonia.

Thus, the objectives of this study are:

1. To hypothesize the probable origin of the plants used through the identification of the timber at the family/genus/species level.

2. To understand the reasoning behind the wood species selection for construction purposes through the evaluation of the wood-related technological knowledge of the Etruscan carpenters.

Overall, this study aims to shed light on the technological, economic and social aspects of the inhabitants of the Domus of the Dolia, and, in a sense, of the Etruscan community of Vetulonia.

\section{Archaeological Settings}

\subsection{The Etruscan City of Vetulonia and the Discovery of the Domus of the Dolia}

Vetulonia is located in Southern Tuscany, and it was an important city during Etruscan times. It ruled in a vast territory, extremely rich in natural resources such as metals, mined in the so-called area of the Colline Metallifere. During the first centuries of its Etruscan history (the 9th-11th centuries BC) it was a vital centre, full of artisan shops, well known for its bronze workers and goldsmiths [20]. Between the 8th and the 6th centuries BC, Vetulonia was the most important of the 12 Etruscan city states, and it survived to the Roman expansion of the 2nd century BC. Nevertheless, it was forced to become an ally of Rome, maintaining his own identity. This was a period of prosperity for the city. The beginning of the Etruscan Vetulonia decline was the result of its involvement in the Roman civil war, which led to the destruction of the city in the 1st century BC [21].

The name of the ancient town of Vetulonia had disappeared from official documents in 1201. The first archaeological works, which lasted from 1882 to the early stage of the 1900s, were conducted by Dr. Isidor Falchi [22]. Falchi discovered the funerary area of the city, discovering both the tombe a pozzetto (pit tombs) from the Iron Age- the Villanovan phase of Etruscan Culture (end of the 9th and the beginning of the 8th centuries BC) - and the majestic tumulus tombs, attributable to the so-called Etruscan Orientalizing Period (from the 8 th century to $580 \mathrm{BC}$ ) $[23,24]$. Moreover, the excavations led also to the discovery of 
the ancient Etruscan city which, with the royal decree of 22 July 1887, regained the ancient Etruscan name of Vetulonia [22]. The excavations conducted by Falchi were concentrated in the area known as Poggiarello Renzetti, where the Etruscan-Roman district of the city was brought to light (Figure 1).

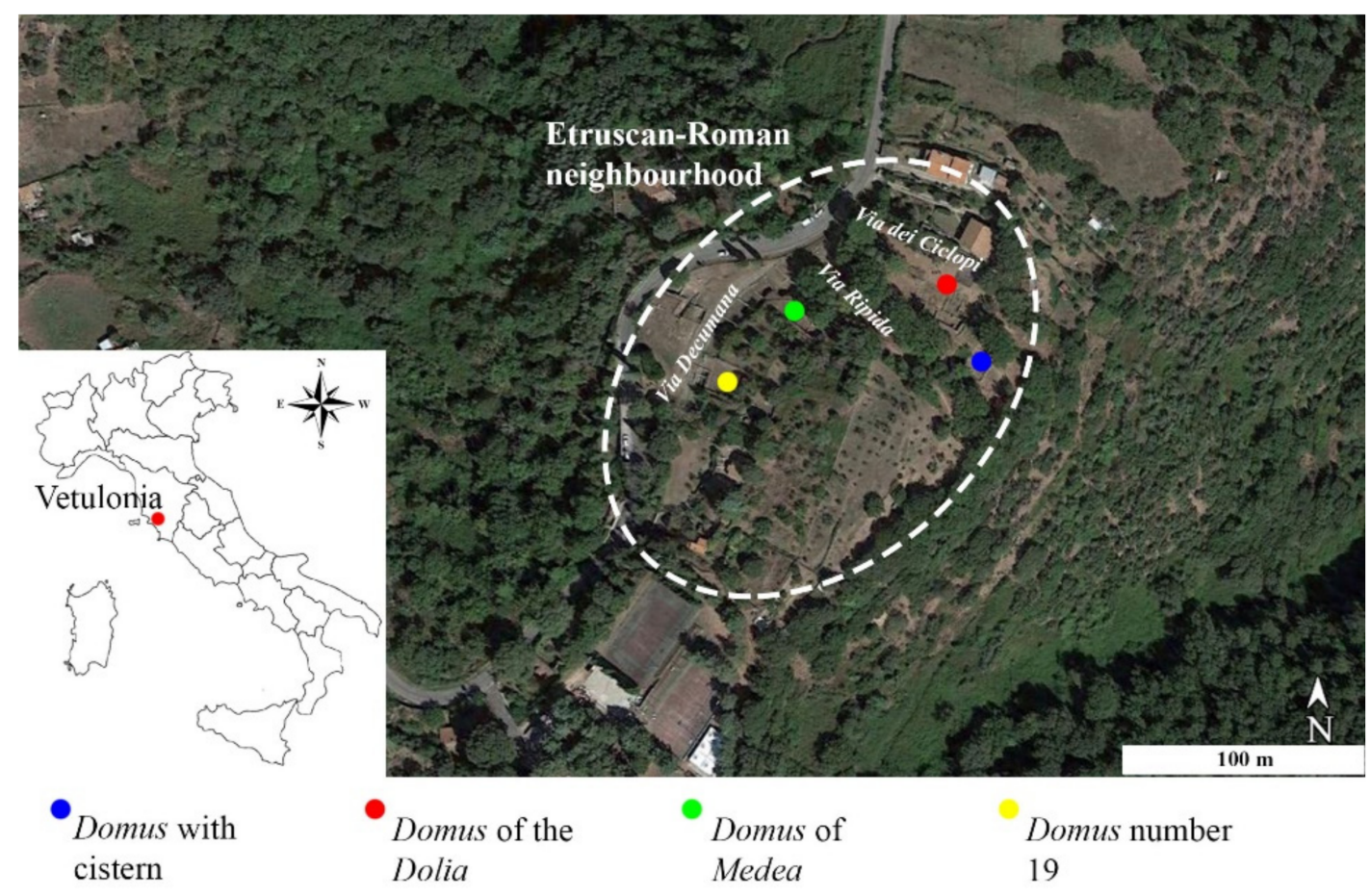

Figure 1. The Etruscan district of Poggiarello Renzetti. Source: Google Earth Pro.

The area was the subject of new archaeological excavations in late 1980 by the superintendent Mario Cygielman, who discovered the Domus of Medea [25]. Other archaeological evidence of the urban Etruscan area was excavated by Anna Talocchini between 1960 and 1970, referring to the sanctuary part of the city (i.e., the Acropolis). These are the areas of Costia Lippi and Costa Murata, both chronologically attributable to the Hellenistic (4th-3rd centuries BC) and to the Late Republican periods (2nd-1st centuries BC), respectively [26,27]. In addition, some evidence (i.e., pottery) suggested that the area of Costa Murata was already occupied (in the second half of the 6th and the middle of the 5th centuries BC) during the archaic period [28]. Furthermore, the well-known Mura dell'Arce, first discovered by Isidoro Falchi at the end of 1800, which-according to new research-refers to a chronological period between the 3rd and the 2 nd centuries $\mathrm{BC}$, are worth mentioning [23,28]. Finally, in 2009, under the direction of Simona Rafanelli (current director of the Etruscan Museum of Vetulonia), a new archaeological excavation took place in the Poggiarello Renzetti area (the Etruscan-Roman neighborhood discovered by Falchi), and the Domus of the Dolia was brought to light [29].

The archaeological area of Poggiarello Renzetti represents the richest area of Etruscan Vetulonia settlements. The district is crossed by a large, paved street, called via Decumana, which overlooks numerous shops and private houses. In the north-eastern part of the main road network there are two perpendicular streets, respectively known as the via Ripida and the via dei Ciclopi [30,31]. It is within the insula defined by these three paths that the Domus of the Dolia was discovered. The Domus supports other residential Etruscan structures of Hellenistic period (4th-1st centuries BC) such as the Domus n. 19, the Domus of Medea, and the Domus characterized by the presence of a vast atrium with impluvium and of an adjacent large cistern carved into the rock [31-33], (Figure 1). The Hellenistic quarter of Poggiarello Renzetti represents, therefore, with its important housing structures, the 
most striking archaeological evidence of the revival of Vetulonia to new splendour with a building and economic renaissance, which started from the 3rd century BC.

\subsection{Archaeological Evidence of the Domus of the Dolia}

The Domus of the Dolia was destroyed by a fire. The classification of the recovered archaeological materials, such as black-painted ceramic and Greek-Italic amphorae, suggest a chronology between the 3rd and the 1st centuries BC. It is known that the Etruscan city was destroyed by the troops of Lucio Cornelio Silla in the 1st century BC, in the aftermath of the victory over Gaius Mario's army during the Roman civil war [34].

This Domus represents an exceptional discovery for the archaeological area of Vetulonia and for Etruscan archaeology, as well-preserved dwellings with high rises (over $1.60 \mathrm{~m}$ and about $6 \mathrm{~cm}$ in thickness) have rarely been found. Moreover, because of the fire, the roof collapsed, sealing and preserving an old context with a wide variety of materials.

The building is divided into about 12 rooms (the excavation is still underway) (Figure 2), and from the excavation data (ongoing study) it seems to have had three construction phases. Phase I (beginning of the 3rd century BC) seems to have included five different rooms (A, C, E, G and D) arranged to the south. Rooms E and G seem to have been interconnected, and Room D probably served as a house entrance at this stage. From the II phase on (2nd century BC), Room E was separated from Room G, becoming one of the most important rooms of the house. From this phase, the Domus seemed to be arranged around a big semi-open courtyard-Room D-which, after being refurbished, become the first atrium of the house, possibly with an impluvium. Furthermore, during this phase, Rooms F and H (a courtyard with a portico) and room B (product processing area) were likely built. During phase III (between the 2nd and the beginning of the 1st century BC) the Domus was expanded to the north with the addition of other rooms (e.g., P, S) and a large peristyle (K). During this phase of the house's life, Room E seems to have replaced the function of Room C, becoming the most important room of the house. The Domus was configured like that until its destruction [34].

Many precious remains were recovered inside the Domus, revealing the richness of this building and its inhabitants. From one of the most significant rooms of the house, the formal dining room, the Triclinium (Room C), archaeologists recovered a small white limestone column, a precious bowl decorated with an animal head, and a few bronze coins, possibly associated to a foundation ritual related to the new life-phase of the house [29]. This room was also characterized by painted walls with red and blue frescos belonging to the first Pompeian style [35]. The Domus also included a representative guest reception room, the Tablinum (Room E), with a beautiful floor decorated with a meander motif, formed by white and grey limestone tiles and plaster (Opus Signinum style). The walls of this room were also decorated with frescoes $[29,35]$. Inside the two storage rooms (Rooms A and G) many amphoras and big earthen pots (Dolia) were discovered, one of which is about $1.20 \mathrm{~m}$ high and is still almost intact. The uniqueness of these discoveries justifies the name of the Domus. Moreover, in the storage room G a small treasure was also discovered, consisting of some votive bronzes. The house also included a room perhaps associated with grape or olive processing (Room B) [34]. The architecture of the Domus seems to refer to a specific type of rural aristocratic housing with a peristyle court, diffuse in the Attic region from the 5th century BC, called Pastas style. This type of dwelling is well documented in the southern part of the Italian peninsula during the Hellenistic age [36,37].

The material employed for the construction of the Domus of the Dolia was sandstone, which was extracted for the construction of the perimeter walls. In some rooms, the walls were probably finished by using raw clay material. Tiles and brick tiles were used to cover the roof, while raw bricks were employed in the structure of some of the internal divisions of the house. Wood was utilized for the construction of the room's framing elements, for the doors and maybe for the internal support of the raw clay parts of the walls, which were probably built with a different kind of technique [29]. It is important to report that 
no wooden remains associated with the building process of the raw clay walls have been retrieved. Moreover, the few raw clay remains bring back the negative of small stem reeds.
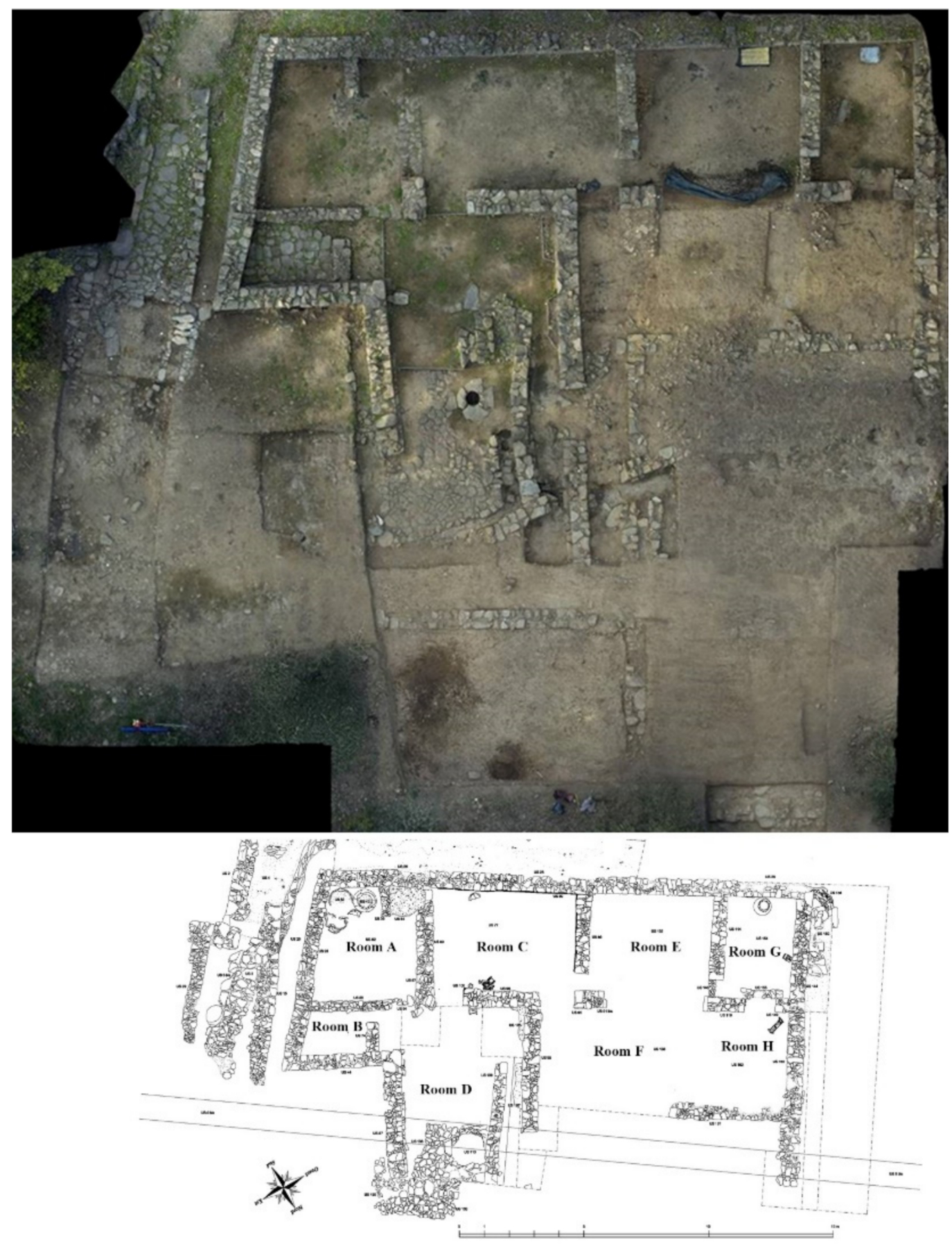

Figure 2. Domus of the Dolia divisions, pictures by Paolo Nannini and Stefano Spiganti.

From the archaeological data and from the Domus typology, we can assume that the house was supplied with light from the central courtyard; therefore, the presence of windows in the investigated area of the house is not expected. The huge Domus of the Dolia, containing several compartments with various well-preserved and precious materials uncovered within the wood charcoal remains (i.e., the object of this study) represents a unique case for Etruscan archaeology. 


\section{Materials and Methods}

\subsection{Materials and Sampling}

The materials analysed comprise wood charcoal remains belonging the first archaeological campaigns (2011-2016) of the Domus of the Dolia. These archaeological campaigns were conducted within the better-preserved part of the house, the southern part, which was the most relevant investigated area due to the presence of collected wood charcoal evidence. The northern part of the house (excavation ongoing) was largely destroyed by agricultural works, and the archaeobotanical evidence is scarce or absent. The wood charcoal remains under study are representative of the II and III rebuilding phases of the Domus, which was ultimately ruined and buried under the fire. The charred wood samples come from seven different compartments of the house, namely Room A (storage), Room C (Triclinium), Room D (semi-open courtyard-first atrium), Room E (Tablinum), Room F (court), Room G (storage) and Room H (semi-open room with portico) (Table 1; Figure 2).

Anthracological analyses were not included in the initial planning of the archaeological excavation. For this reason, most of the wooden material under study was identified visually, collected by hand (in small and restricted areas), drawn and documented. This material consisted of large charred wooden elements, generally broken/fragmented (the largest fragments were $5 \mathrm{~cm}$ in diameter), that were interpreted by the archaeologists as wooden roof framing elements based on their size, position and context during the excavation (Table 1; Figure 3).

Table 1. Domus of the Dolia. The provenance and number of the charcoals analysed, and their archaeological ascription (SU stratigraphic unit).

\begin{tabular}{|c|c|c|c|c|c|}
\hline \multirow{2}{*}{ Room } & \multirow{2}{*}{ SU } & \multicolumn{2}{|c|}{ Sample Excavation Data } & \multirow[b]{2}{*}{$\begin{array}{l}\text { Wood Charcoal from } \\
\text { Dark/Black Areas }\end{array}$} & \multirow{2}{*}{$\begin{array}{l}\text { No. of Wood Charcoal } \\
\text { Fragments }\end{array}$} \\
\hline & & Classification/Information & $\begin{array}{l}\text { Charred Wooden } \\
\text { Elements }\end{array}$ & & \\
\hline \multirow[t]{2}{*}{$\mathbf{A}$} & 61 & Wooden roof framing elements & 2 & & 20 \\
\hline & 62 & Wood charcoals & & $\mathrm{x}$ & 60 \\
\hline \multirow[t]{3}{*}{$\mathrm{C}$} & 77 & Wood charcoals-close to nails & & $\mathrm{x}$ & 9 \\
\hline & 98 & Wood charcoals & & $\mathrm{x}$ & 48 \\
\hline & 102 & Wood charcoals-close to nails & & $\mathrm{x}$ & 80 \\
\hline D & 111 & Wooden roof framing element & 1 & & 10 \\
\hline \multirow[t]{2}{*}{$\mathbf{E}$} & $128 / 129$ & Wood charcoals & & $\mathrm{x}$ & 71 \\
\hline & 129 & Wood charcoals-close to nails & & $\mathrm{x}$ & 55 \\
\hline $\mathbf{F}$ & 166 & Wood charcoals & & $\mathrm{x}$ & 34 \\
\hline \multirow[t]{14}{*}{ G } & 143 & Wooden roof framing elements & 3 & & 30 \\
\hline & 143 & Wood charcoals & & $\mathrm{x}$ & 50 \\
\hline & 143 & Wooden roof framing element & 1 & & 10 \\
\hline & 143 & $\begin{array}{l}\text { Wood charcoals with plaster-near } \\
\text { the collapse }\end{array}$ & & $\mathrm{x}$ & 65 \\
\hline & 143 & Wood charcoals-corner of the room & & $\mathrm{x}$ & 27 \\
\hline & 145 & $\begin{array}{c}\text { Wood charcoals from the interior of } \\
\text { a Dolium }\end{array}$ & & $\mathrm{x}$ & 26 \\
\hline & 145 & Wood charcoals & & $\mathrm{x}$ & 25 \\
\hline & 146 & $\begin{array}{l}\text { Wooden roof framing } \\
\text { element-corner of the room }\end{array}$ & 1 & & 10 \\
\hline & 146 & $\begin{array}{l}\text { Wooden roof framing } \\
\text { elements-close to a Dolium }\end{array}$ & 2 & & 20 \\
\hline & 147 & Wood charcoals-close to nails & & $\mathrm{x}$ & 50 \\
\hline & 151 & Wooden roof framing element & 1 & & 10 \\
\hline & 151 & $\begin{array}{l}\text { Wood charcoals-close to amphorae } \\
\text { and nails }\end{array}$ & & $\mathrm{x}$ & 315 \\
\hline & 152 & Wooden roof framing element & 1 & & 10 \\
\hline & 152 & $\begin{array}{l}\text { Wood charcoals-centre of the } \\
\text { room/near votive bronzes }\end{array}$ & & $\mathrm{x}$ & 150 \\
\hline \multirow[t]{2}{*}{$\mathbf{H}$} & 159 & Large and elongated wooden piece & 1 & & 10 \\
\hline & & Total & & & 1195 \\
\hline
\end{tabular}


However, it must be considered that most of the wooden components of the Domus were destroyed by the fire and by the collapse of the roof; the attribution of the material, during the excavation, to a single original wooden element was not always possible. These uninterpreted wood charcoal remains were generally dispersed in wider dark/black areas of the archaeological layers. Attempts were made to collect the entirety of the remains in these darkened areas, but some smaller charcoal fragments may have been lost. Within the category of wood charcoal from the dark/black areas, one should also consider the possibility that remains from furniture and different furnishings/objects of the Domus could also be present in the samples recovered for analysis.
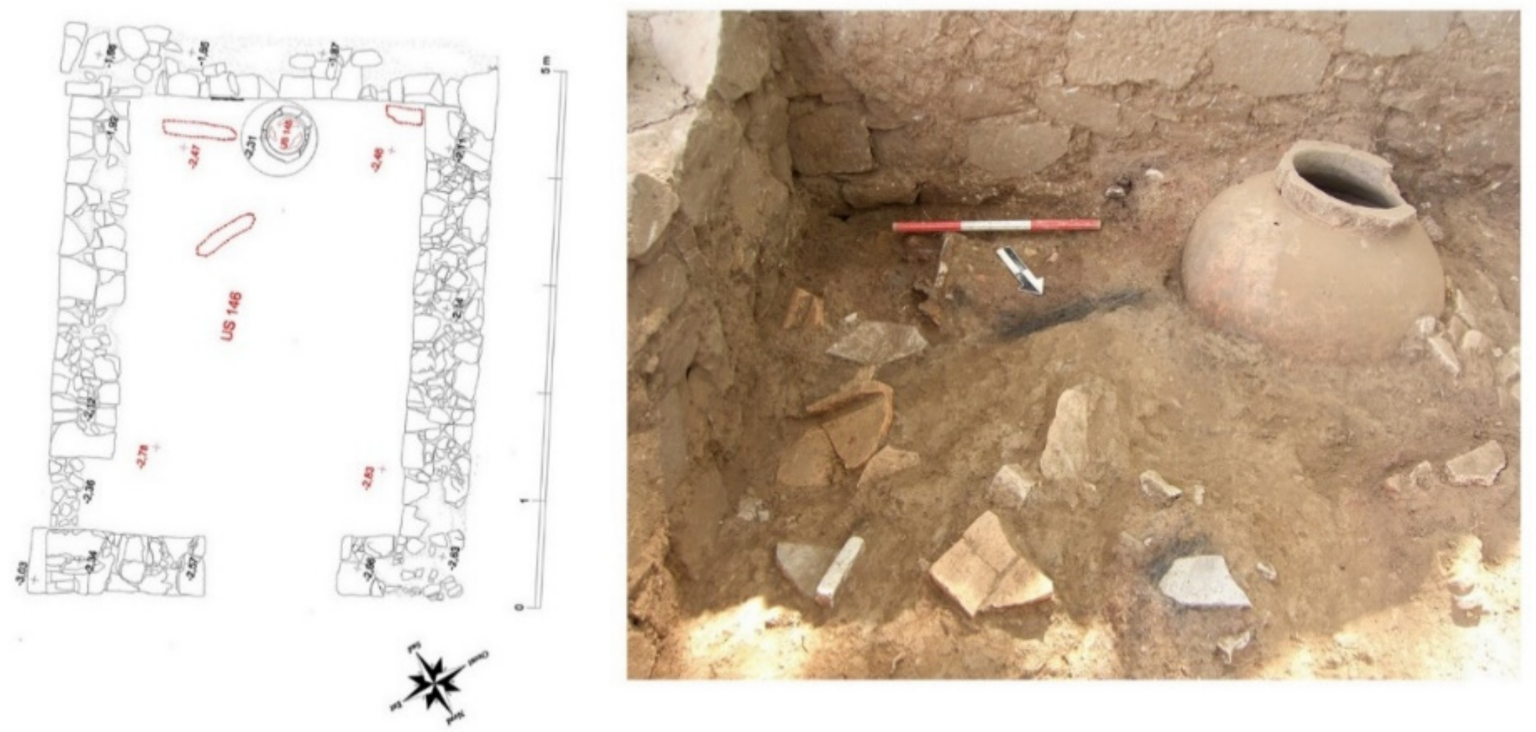

Figure 3. Drawing and a picture of the different wooden roof framing elements identified in Room G. Picture and drawing by Stefano Spiganti.

From the material retrieved from the excavation, and given its fragmentary nature, the sampling of the wood charcoal remains was organised in the following way: for each charred wooden element identified during the archaeological excavation, 10 of the largest fragments were selected in order to confirm their provenance from the same tree species; the samples not identified during the excavation phase (samples from the dark/black areas) were studied in their totality.

\subsection{Anthracological Analysis}

The charcoal fragments were manually fractured to expose the three diagnostic sections (transversal, tangential and radial) under a stereo-zoom microscope (LEICA M205C equipped with a camera). The charcoal's anatomical features were determined on a Reflect Light Optical Microscope (LEICA DM2500 equipped with a camara) at different magnifications (5-100x). A selection of charcoal fragments was analysed with a Scanning Electron Microscope (SEM) to obtain high-resolution images. Analyses were performed using a variable pressure HITACHI S3700N SEM, and the operating conditions for the analysis were as follows: secondary electron mode (SE), $10 \mathrm{kV}$ accelerating voltage, $10 \mathrm{~mm}$ working distance, $65 \mu \mathrm{A}$ emission current and $<1$ Pa pressure in the chamber. All of the samples were covered with a gold layer prior to the analysis. Wood atlases [38-41] were used as comparative tools for the charcoal identification, together with an in-lab reference collection of wood specimens. The analysis identifies wood charcoals fragments at the highest possible taxonomical level (family/genus/section/species). The level of identification depends, in fact, on the available and visible diagnostic micro-anatomical characters of single wood species/specimens. Some other types of observation were also made. For samples identified as building elements, in fact, when possible, the growth ring 
curvature was observed [42-45]. When present, galleries of xylophagous insects were also recorded $[43,46]$.

For most of the charcoal samples, the identification of the species was possible, although in some cases the degradation of the wood only allowed for the identification of the genus or the family. In this case, the name of the genus is followed by the abbreviation of species (sp.), i.e., Acer. sp. When the species attribution is highly probable, the abbreviation (cf.) is placed between the name of the genus and the name of the species, i.e., Prunus cf. avium.

Regarding the identification of the wood belonging to the genera Abies (fir wood) and Fagus (beech wood), their anatomy does not allow any distinction between the species [41,47], but considering the investigating period and the present-day distribution, they can be ascribed to Abies alba and Fagus sylvatica, respectively.

For the distinction in Quercus (deciduous, semideciduous and evergreen sections) we followed the indication of Cambini [38]. These guidelines distinguish the deciduous oaks (Quercus sect. robur) from the semideciduous (Quercus sect. cerris) and the evergreen (Quercus sect. suber). In Italy, the deciduous oak group includes Quercus robur L., Quercus pubescens Wild., Quercus frainetto Ten. and Quercus petrea (Matt) Liebl.; the semideciduous include Quercus cerris L., Quercus trojana Webb and Quercus aegilops L.; the evergreens include Quercus suber L., Quercus ilex L. and Quercus coccifera L.

\subsection{Quantification}

Regarding the quantification analysis, it is generally advisable to previously determine which may be the most useful and relevant method to be used in a particular occurrence [48-50]. In this case study, two different quantitative methods were employed: the frequency and the ubiquity correction [51,52]. The frequency (\%), based on the absolute number of charcoal fragments, was employed in order to evaluate the different categories of wood charcoals of which the provenience was attributed over the context of the Domuswood roof framing elements, furnishing and court tree/s. The ubiquity correction $(\% \mathrm{U})$ was used to show the occurrence of a tree species across the Domus of the Dolia contexts.

These methods considered only wood charcoal fragments coming from the dark/black areas. An assessment based only on the quantification of the taxa identified as single wood elements during the excavation would potentially obscure the importance of some taxa as building material.

\section{Results}

In total, 1195 wood charcoal fragments coming from seven different compartments of the house-rooms A, C, D, E, F, G, H-were analysed and identified.

A total of nine taxa were identified. Amongst them were Abies cf. alba, Acer sp., Buxus sempervirens, Fagus cf. sylvatica, Prunus cf. avium, Quercus sect. cerris, Quercus sect. robur, Quercus sect. suber and Rosaceae (Table 2, Figures 4 and 5).

The most exploited woods for the construction of the roof of the Domus of the Dolia were deciduous and semideciduous oak and silver fir wood (Table 2). Deciduous and semideciduous oak wood accounts for the highest number of wood charcoal fragments identified; silver fir wood is the most recurrent taxon across the different rooms of the Domus (Table 3). Wood roof framing elements account for $66.57 \%$ of the total of the charcoal fragments analysed. Evergreen oak wood, boxwood, beech wood, maple wood and cherry wood were used for the furniture of the house and the furnishing objects of the house. Furnishing woods account for $30.23 \%$ of the total. Charcoal fragments belonging the Rosaceae family were probably part of a tree/s of the garden of the court of the house, accounting for 3.19\% of the total (Figure 6). 
Table 2. Plant source and possible interpretation (SU stratigraphic unit).

\begin{tabular}{|c|c|c|c|c|}
\hline Room & SU & $\begin{array}{c}\text { Interpretation Based on the Archaeological and } \\
\text { Archaeobotanical Data }\end{array}$ & Plant Source & $\begin{array}{l}\text { No. of Wood } \\
\text { Charcoal Fragments }\end{array}$ \\
\hline \multirow[t]{3}{*}{ A } & 61 & Roof beams or rafters & Quercus sect. robur & 20 \\
\hline & 62 & Fragments of wooden roof beam $/ \mathrm{s}$ or rafters $/ \mathrm{s}$ & Quercus sect. robur & 15 \\
\hline & 62 & Fragments of wooden roof beam/s or rafter/s & Abies cf. alba & 45 \\
\hline \multirow{4}{*}{$\mathrm{C}$} & 77 & Fragments of wooden roof beam $/ \mathrm{s}$ or rafter/s & Quercus sect. cerris & 9 \\
\hline & 98 & Fragments of wooden furniture & Fagus cf. sylvatica & 48 \\
\hline & 102 & Fragments of wooden roof beam/s or rafter/s & Quercus sect. cerris & 30 \\
\hline & 102 & Fragments of wooden roof beam $/ \mathrm{s}$ or rafter/s & Abies cf. alba & 50 \\
\hline D & 111 & Roof beam or rafter & Quercus sect. cerris & 10 \\
\hline \multirow[t]{2}{*}{$\mathbf{E}$} & $128 / 129$ & Fragments of a Kline bed foot & Buxus sempervirens & 71 \\
\hline & 129 & Fragments of wooden roof beam $/ \mathrm{s}$ or rafter $/ \mathrm{s}$ & Abies cf. alba & 55 \\
\hline $\mathbf{F}$ & 166 & Fragments of fruit tree/s of the courtyard & Rosaceae & 34 \\
\hline \multirow[t]{13}{*}{ G } & 143 & Roof beams or rafters & Quercus sect. robur & 30 \\
\hline & 143 & Fragments of wooden roof beam $/ \mathrm{s}$ or rafter $/ \mathrm{s}$ & Quercus sect. robur & 50 \\
\hline & 143 & Roof beam or rafter & Abies cf. alba & 10 \\
\hline & 143 & Fragments of wooden roof beam $/ \mathrm{s}$ or rafter $/ \mathrm{s}$ & Abies cf. alba & 65 \\
\hline & 143 & Fragments of wooden tool & Acer sp. & 27 \\
\hline & 145 & Fragments of wooden roof beam $/ \mathrm{s}$ & Quercus sect. robur & 25 \\
\hline & 145 & Fragments of a jar lid of a Dolium & Prunus cf. avium & 26 \\
\hline & 146 & Roof beams or rafters & Quercus sect. robur & 30 \\
\hline & 147 & Fragments of wooden roof beam/s or rafter/s & Quercus sect. robur & 50 \\
\hline & 151 & Roof beam or rafter & Quercus sect. robur & 10 \\
\hline & 151 & Fragments of wooden roof beam/s or rafter/s & Quercus sect. robur & 315 \\
\hline & 152 & Roof beam or rafters & Quercus sect. robur & 10 \\
\hline & 152 & Components of a container/support of votive bronzes & Quercus sect. suber & 150 \\
\hline $\mathbf{H}$ & 159 & Dividing door of rooms $\mathrm{G}$ and $\mathrm{H}$ & Prunus cf. avium & 10 \\
\hline \multicolumn{4}{|c|}{ Total } & 1195 \\
\hline
\end{tabular}

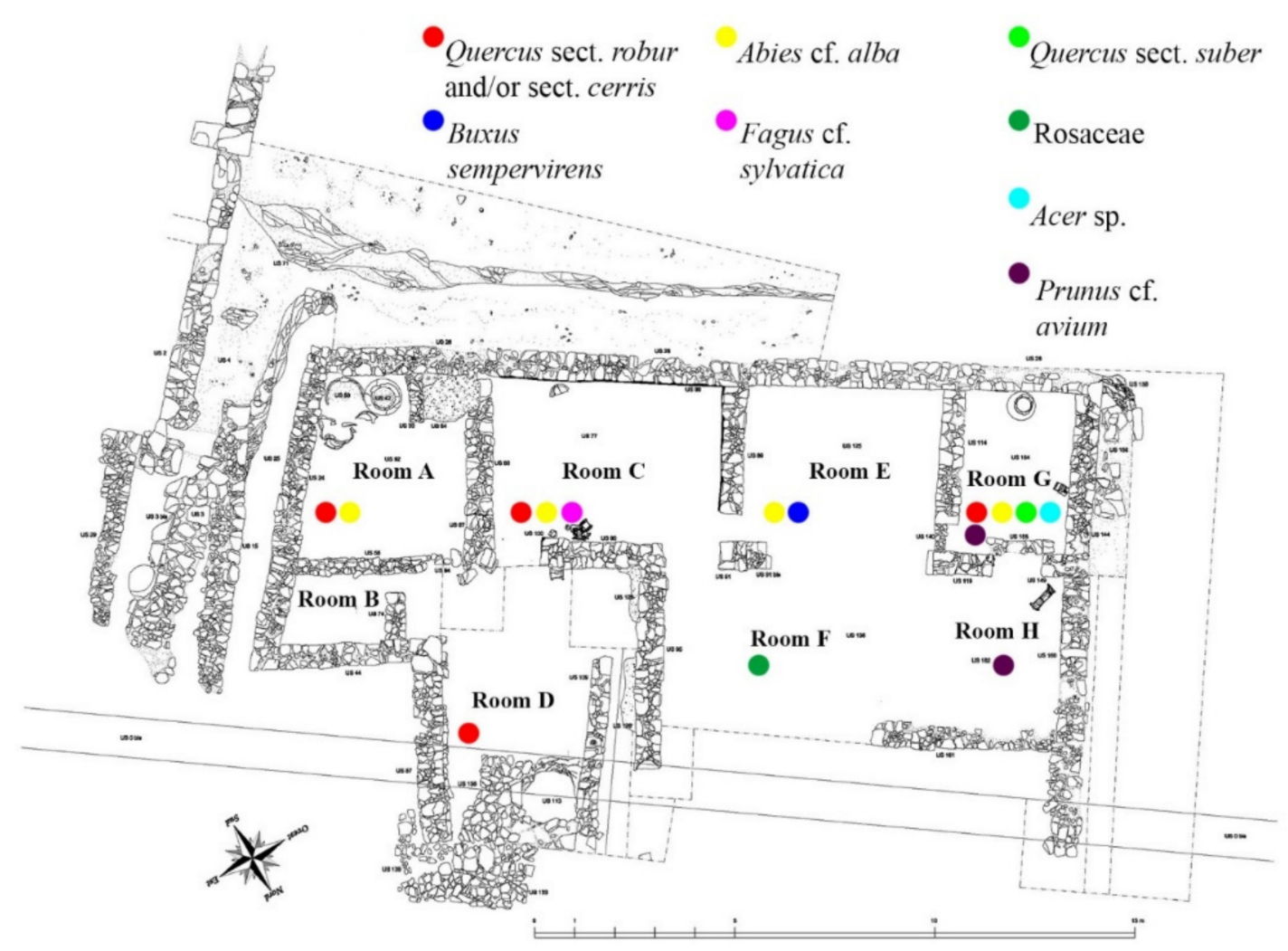

Figure 4. Plant source distribution in the different rooms of the Domus of the Dolia. 
Table 3. Plant source occurrences in the different divisions of the Domus of the Dolia (samples from the dark/black areas).

\begin{tabular}{|c|c|c|c|c|c|c|c|c|c|}
\hline \multicolumn{10}{|c|}{ Plant Source } \\
\hline & $\begin{array}{l}\text { Quercus sect. robur } \\
\text { and sect. cerris } \\
\text { (Deciduous and } \\
\text { Semideciduous Type) }\end{array}$ & $\begin{array}{l}\text { Abies cf. } \\
\text { alba }\end{array}$ & $\begin{array}{l}\text { Quercus } \\
\text { sect. suber } \\
\text { (Evergreen } \\
\text { Type) }\end{array}$ & $\begin{array}{l}\text { Buxus sem- } \\
\text { pervirens }\end{array}$ & $\begin{array}{l}\text { Fagus cf. } \\
\text { sylvatica }\end{array}$ & Rosaceae & Acer sp. & $\begin{array}{l}\text { Prunus cf. } \\
\text { avium }\end{array}$ & \\
\hline Room & \multicolumn{8}{|c|}{ No. of Wood Charcoal Fragments } & Total \\
\hline $\mathbf{A}$ & 15 & 45 & & & & & & & 60 \\
\hline $\mathrm{C}$ & 39 & 50 & & & 48 & & & & 137 \\
\hline $\mathbf{E}$ & & 55 & & 71 & & & & & 126 \\
\hline $\mathbf{F}$ & & & & & & 34 & & & 34 \\
\hline G & 440 & 65 & 150 & & & & 27 & 26 & 708 \\
\hline Total & 494 & 215 & 150 & 71 & 48 & 34 & 27 & 26 & 1065 \\
\hline$\%$ & 46.38 & 20.19 & 14.08 & 6.67 & 4.51 & 3.19 & 2.54 & 2.44 & 100.0 \\
\hline$\% U_{t}$ & 23.12 & 32.87 & 4.24 & 11.27 & 7.01 & 20 & 0.76 & 0.73 & 100.0 \\
\hline
\end{tabular}
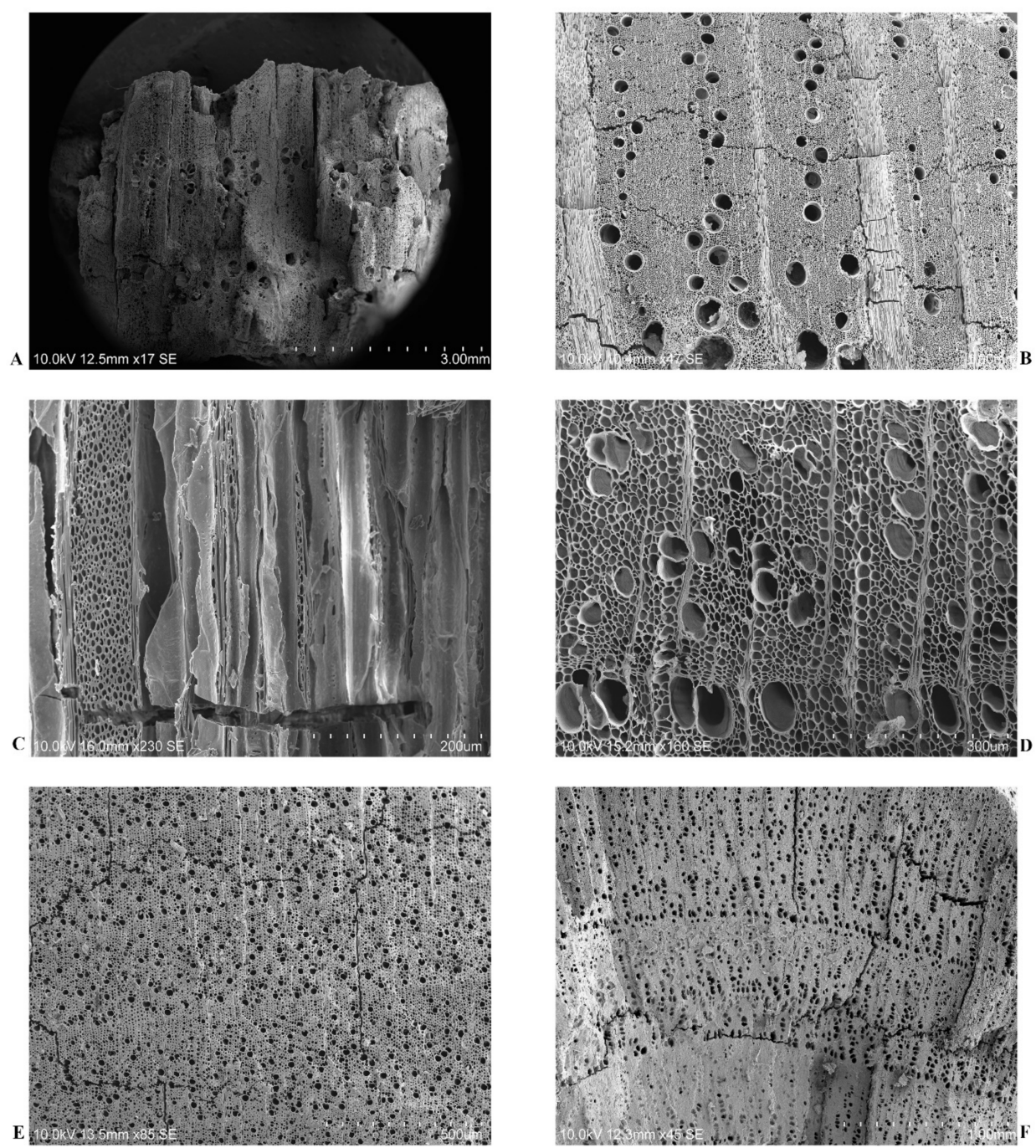

Figure 5. Transversal section of Quercus sect. robur (A); transversal section of Quercus sect. cerris (B); tangential section of Fagus cf. sylvatica (C); transversal section of Prunus cf. avium (D); transversal section of Buxus sempervirens (E); transversal section of Rosaceae (F). 
Regarding the tree ring observation, fragments interpreted as wooden roof framing elements (including those identified during the excavation and those from the dark/black areas) it was not possible to identify a curvilinear trend of the tree growth rings. Tyloses were observed in the lumen of the spring wood vessels of 350 samples identified as $Q$. sect. robur. Galleries formed by xylophagous insects were observed in 85 samples of $Q$. sect. robur, seven samples of $Q$. sect. cerris, 174 samples of $A$. cf. alba and 23 samples of F. cf. sylvatica (Figure 7). The presence of bark was not detected for any of the samples under study.
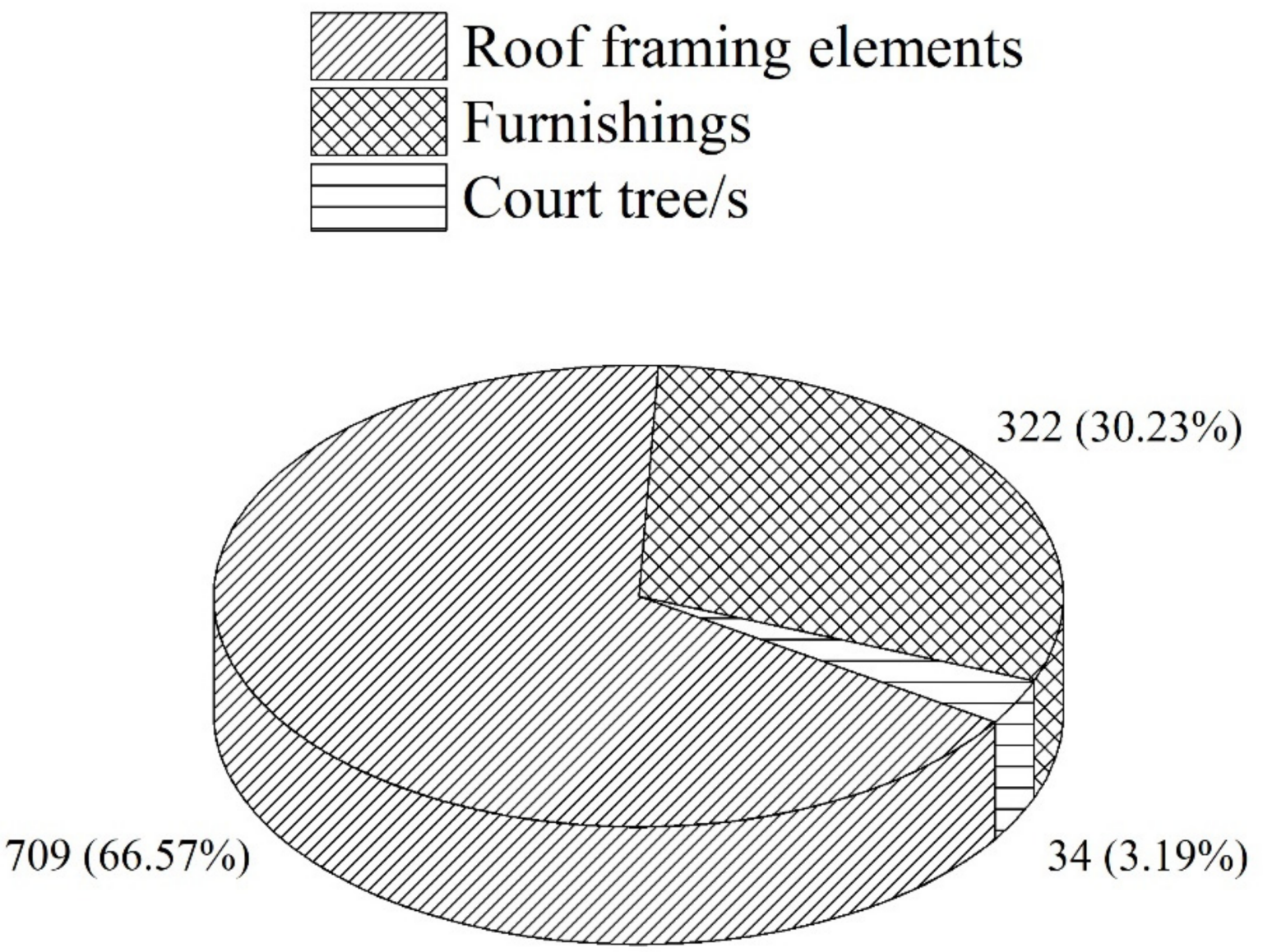

Figure 6. Percentages of the roof framing elements, furnishings and court tree/s identified. 

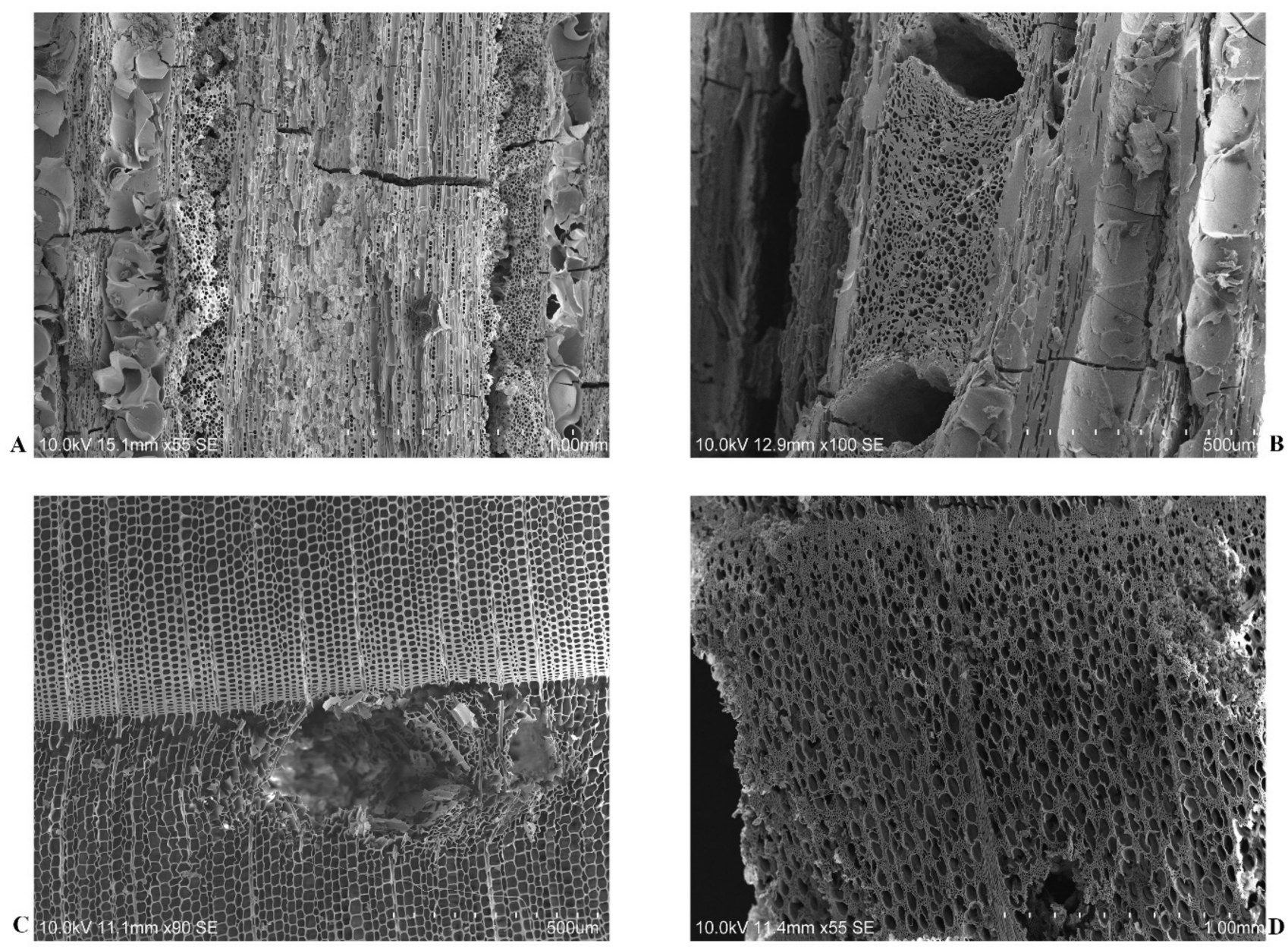

Figure 7. Tyloses in the lumen of the spring vessels of a Quercus sect. robur fragment (tangential section) (A); xylophagous' galleries affecting a Quercus sect. cerris fragment (tangential section), Abies cf. alba fragment (Transversal section) and Fagus cf. sylvatica fragment (Transversal section) (B-D).

\section{Discussion}

\subsection{Different Wood Species for Different Uses}

\subsubsection{Wooden Roof Framing Elements}

Relating to the charred woods identified, those employed for the construction of the Domus of the Dolia were Q. sect. robur (deciduous type), Q. sect. cerris (semideciduous type) and $A$. cf. alba (silver fir wood) (Table 2). The wood charcoal samples belonging to these species were interpreted as the beams or rafters which made up the roof of the Domus. As previously reported, some of these wooden elements were identified during the archaeological excavation. In these cases, the taxa identification supported the archaeological interpretation. The archaeological data, along with the state of conservation of these wooden remains, did not allow any distinction between the beams and/or the smallest rafters. In any case, the traces and the position in the archaeological layers of some of these elements made it possible to understand the type of roof covering some parts of the house. Concerning the four rooms aligned in the southern part of the house (A, C, E, $\mathrm{G})$, the covering was a single pitch roof. The roof pitch was angled from above to below, where the compluviate rooms were located. In the case of the wood charcoals found in the dark/black areas, the preservation state of the samples and /or their burial conditions did not allow any interpretation during the excavation phase. In these circumstances, the interpretation was possible due to a careful study of the excavation data and of the physical and mechanical characteristics of the identified woods. The comparison with other archaeological realities (e.g., where the same species of woods had also been employed for 
the same purposes) was also useful for their interpretation. Numerous charcoal samples were retrieved in association with many nails bent at right angle (Table 1). The discovery of the nails used to fasten the beams/rafters was a further clue which allowed for the interpretation of these wooden elements.

The deciduous and semideciduous oak wood (i.e., Q. sect. robur and $Q$. sect. cerris) was exploited for the manufacturing of the roof beams and/or of the rafters of rooms A, C, D and G. Eleven roof beams/rafters made of this wood were identified during the archaeological excavation as single elements, whilst other wood remains of this species were retrieved in a fragmentary state (a sampling of the charred woods coming from the dark/black areas) (Table 1).

This type of oak wood is well appreciated for its properties, especially for the mechanical strength and the durability of its heartwood, as its high content of tannins preserves it from biological attacks [53]. Vitruvius and Pliny praised the qualities of this wood [54]. Its use for the manufacture of structural elements has been well attested since prehistoric times, and oak forests cover large geographical areas included in the Mediterranean basin [55]. Numerous studies have attested to the use of oak wood for building during Italian prehistory [56-63], as well as for the historical periods $[64,65]$. The widespread use of deciduous and semideciduous oak wood for the beams, rafters, columns and boards of many Roman buildings, as well as for the construction of naval frames, demonstrate the extent to which Romans appreciated this wood for construction purposes [66-70]. Concerning the Etruscan world, the most interesting parallel is the Etruscan Farm of Pian d'Alma (Tuscany) [10].

The identification of one roof beam/rafter of turkey wood from room D (the first atrium of the house with a possible impluvium) indicates the likely existence of a roof cover (at least partial) in the last phase of the life of the Domus.

It is likely that fir wood (i.e., $A$. cf. alba) was also used for the roof beams and/or for the rafters of several rooms of the Domus of the Dolia, namely rooms A, C, E and G. It was possible to identify only one individual wooden element of this species during the archaeological excavation, while many remains of this species were retrieved only in a fragmentary state (samples of charred woods coming from the dark/black areas) (Table 1). In this study, samples were identified as likely Abies alba, given the wide distribution of this tree in the Italian forests, and in the nearby Mount Amiata. The silver fir is the tallest native tree of the Italian peninsula, reaching $45 \mathrm{~m}$ in height. The tall, slender stem makes it the ideal wood for the construction of poles, boards and beams. The large stem diameter of this species makes it suitable for the creation of large wooden products. Furthermore, this type of wood can be easily split and sawed, making it very suitable for the production of boards [71]. The qualities of the silver fir wood were widely appreciated among the Roman and Greek carpenters [72,73]. Classical authors have described its qualities and prestige with respect to other tree species, especially for its exploitation as building elements [74]. Theophrastus wrote about its incredible resistance to deformation when tilted, as in the case of roof beams [73]. Vitruvius describes it as the perfect wood for construction due to its resistance, lightness, workability, and the length of its stem [75]. Livy revealed its essential role for the construction of the Roman naval fleet [73].

Numerous fragments of woods and charcoals of fir wood were retrieved in several Italian archaeological sites, largely identified as building elements, confirming the widespread use of this wood, as indicated by ancient sources. Many vertical poles of some Italian prehistoric pile dwelling were made of fir wood [57,58,76-78]. Several roof beams and rafters of Romans basilicas, temples and private buildings were made of fir wood, as charcoals and wood remains testify $[40,54,70,73,79-87]$. A large amount of wooden remains of this species related to shipbuilding were also retrieved, testifying to the widespread use of this wood for construction frames [69,88-90]. Finally, wood remains of fir wood were retrieved from the Etruscan Sanctuary of Pyrgi [9].

The large amount of charred wood fragments of $A$. cf. alba recovered inside of the Domus of the Dolia, interpreted as roof framing elements, reinforce the hypothesis that the Etruscans were great exploiters of this wood, as were the ancient Romans and Greeks. 
The final phase of the Domus of the Dolia occupation coincides with increasing Roman control over the Etruscan cities. Roman choices in wood selection became more culturally influential at this time, which is apparent in the evidence of the wood exploitation at this site.

Regarding the compartment E (Tablinum), the peculiar use of silver fir wood for the manufacture of the roof beams/rafters could be a deliberate choice made by the constructors, perhaps at the behest of the family of the Domus of the Dolia. The use of a more valuable wood species would have made the environment of this important room more beloved; this type of room was normally reserved for the reception of guests.

Considering the number of fragments, and their frequency and ubiquity, we can observe that the roof framing elements are the most abundant wood charcoals identified at the Domus of the Dolia. This data should not be surprising, considering that the woods employed for the construction of the roof of the house were used for all of the rooms of the Domus, being present in larger quantities even when the Domus was still alive. Between the wooden roof framing components, deciduous and semideciduous oak wood were identified in a larger quantity compared with silver fir wood (46.38 vs. $20.19 \%)$, while silver fir wood was the most recurrent taxon across the different rooms of the Domus $(32.87 \% \mathrm{U})$ (Table 3). The abundance of deciduous oak wood is intelligible because oak wood is considered, in this context, a local plant source. The higher ubiquity value of silver fir wood could be explained by considering the quality and the beauty of this wood.

\subsubsection{Furniture and Furnishing Objects}

Among the wood charcoals identified, those that were parts of the Domus furniture, furnishings, and other objects (i.e., tools) were: $Q$. sect. suber (evergreen oak group), $B$. sempervirens (boxwood), F. cf. sylvatica (beech wood), Acer sp. (maple wood) and P. cf. avium (likely cherry wood). Wood charcoal remains of these species were retrieved only in a fragmentary state (samples of charred woods coming from the dark/black areas). The study of the excavation data, of the physical and mechanical characteristics of this wood, and the comparison with other archaeological realities made the interpretation of these wood charcoal samples possible.

Regarding the evergreen oak wood remains (i.e., $Q$. sect. suber), they were recovered from Room G of the Domus of the Dolia. The evergreen oak wood employed for the construction of the Domus may belong to one of the following tree species: the cork oak ( $Q$. suber), the holm oak (Q. ilex) or the Kermes oak (Q. coccifera), however it was not possible to distinguish between the various species of this group at the micro-anatomical level.

Evergreen oak wood has been well known since antiquity [66], especially by Romans, who largely used it for the manufacture of objects and furniture. This type of wood has also been used for the covering of sophisticated furniture, given its qualities $[64,65,81]$. Pliny, in his Naturalis Historia, praises its pleasant nature and reports various uses, in particular its employment for the manufacture of small-sized objects, tools and handles [91]. He described its use for the manufacture of the famous Citrus Venus table, owned by the emperor Tiberius [92], and also wrote about its high resistance to friction and considered it very suitable for the construction of wheels [73]. Cato recommended the adoption of this wood for the manufacture of agriculture tools' handles [93]. Wood remains of evergreen oak have been retrieved in several archaeological sites, both Roman and Etruscan $[10,83]$. Wooden remains of this species related to shipbuilding have also been retrieved [67,69].

Wood charcoal fragments of evergreen oak were retrieved from the centre of Room $\mathrm{G}$ of the Domus of the Dolia, in connection with votive bronzes (Figure 8). Wood charcoal remains belonging to this species were only retrieved in a fragmentary state. However, the characteristics of this wood and their sampling position seems to suggest their possible use for the bronze's storage, as they could have been parts of a cabinet or a box containing the bronzes. 


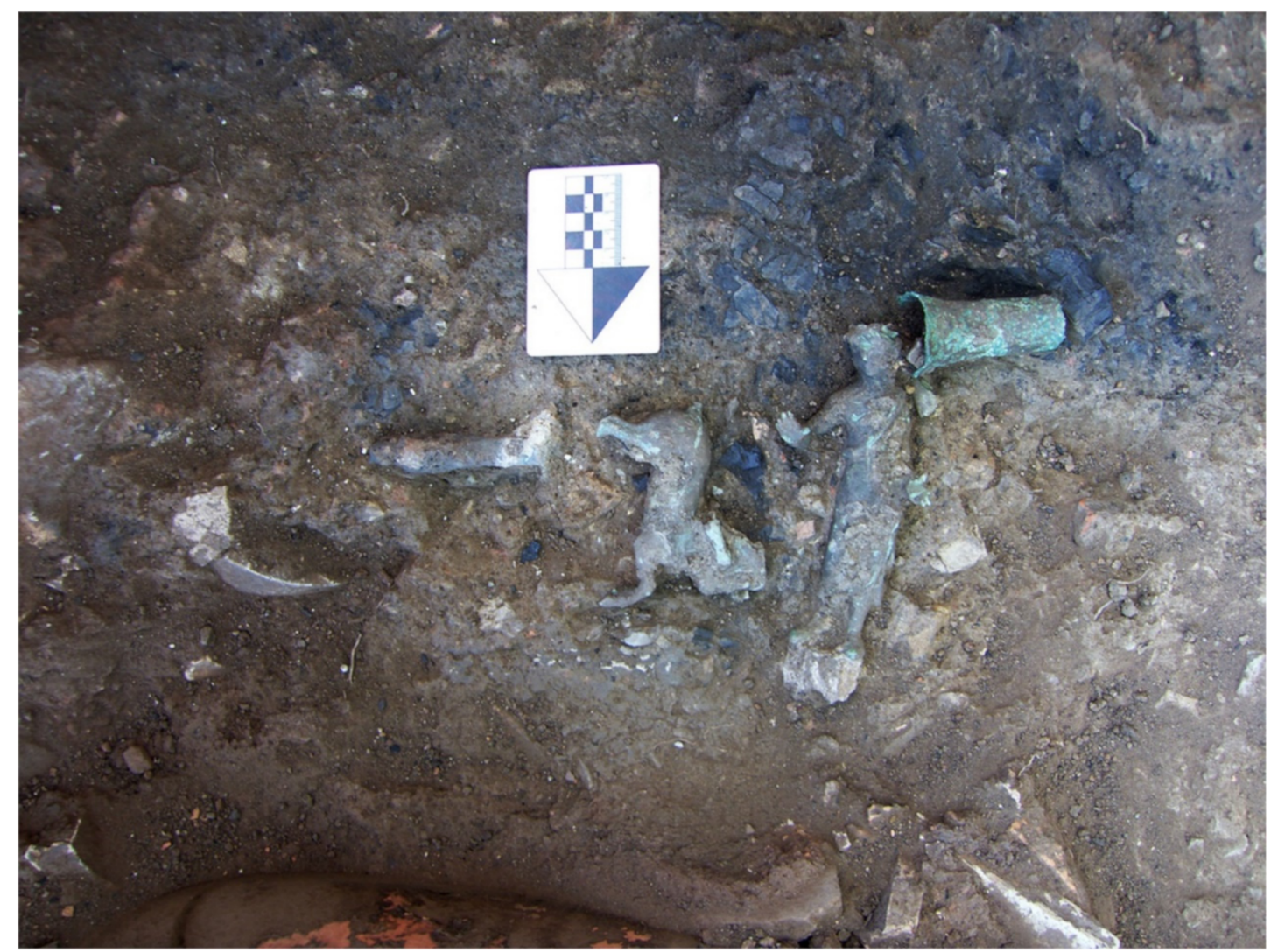

Figure 8. Votive bronzes surrounded by charcoals at the time of the discovery.

With regards to the boxwood fragments (i.e., B. sempervirens), they were recovered from Room E of the Domus of the Dolia.

Boxwood is a small shrub between 2 and $4 \mathrm{~m}$ high, producing a strong and heavy wood. Its use is associated with the art of cabinet making, carpentry, inlay and turnery works. Its qualities of hardness and resistance to chipping made it the favourite wood for the manufacture of combs since ancient times [73]. This wood was valuable and already appreciated by the Assyrians, who considered boxwood wooden furniture to be the spoils of war [94]. Boxwood was also used in Ancient Egypt and in Italy during the Roman Empire for the manufacture of furniture, tool handles, small precious objects, and wind instruments [95]. This wood has been and still is appreciated for the manufacture of stringed instruments, such as organs and pianos [94]. Moreover, it has always been used for the manufacture of tools, and more generally of objects exposed to wear and friction $[55,73]$. Boxwood was mentioned in Latin sources, with Pliny describing it as a hard, resistant and hardly perishable wood [91]; Vitruvius described it as suitable for less-visible works, such as clamps supporting false-plastered vaults [73]; Ovid mentioned its use for the manufacture of flutes [73]. Ancient Greek literature mentioned its use for the construction of convivial beds (Kline) [96]. Archaeological remains of boxwood dating back to prehistoric times attested to the wide use of this wood [97-101]. Finally, the boxwood flutes with the tablet recovered from the shipwreck of the Giglio island coast (600 BC) (Tuscany) are from the Etruscan period [8].

Given the characteristics of this wood and the evidence of its use in the ancient literature fragments, the boxwood charcoal samples from room E of the Domus of the Dolia are likely to be interpreted as part of a foot of a Kline bed, present in this room at the time of the fire in the house. To support this hypothesis, it is important to refer to the fact that the boxwood samples of the Domus of the Dolia were recovered in association with some bronze elements identified as parts of the foot of a Kline bed. The identification of these bronze elements was confirmed by the comparison with a bronze foot of a Greek Kline 
bed currently exhibited at the archaeological museum of Nice. The presence of a Kline bed in the Tablinum of the Domus of the Dolia at the time of the fire is interpreted by the archaeological data as an indication of a second phase of the life of the house, where the Tablinum would have replaced the function of the ancient Triclinium.

Concerning the wood charcoal fragments of beech wood from Room C of the Domus of the Dolia, they were identified as likely being Fagus sylvatica, given the wide distribution of this tree in the Italian greenwoods and the nearby Mount Amiata.

Beech wood has always been highly appreciated for its strength and versatility [73]. It is an easily worked wood, excellent for being finished and folded; for these reasons, it has always been used in the manufacture of all types of home furniture, but its tendency to crack and bend does not make it a suitable wood for building and construction [40,102]. This wood is highly appreciated for the manufacture of floors, stairs and interiors [103]. It was a well-known wood and widely used by Romans, who employed it for the construction of large, decorated chests that furnished gentlemen's bedrooms [104]. Theophrastus mentioned beech wood as one of the most suitable woods for ship masts, furniture, and especially beds [73]; Pliny described it as an easy wood to work, soft and easily breakable [91]; Columella described chests made of beech wood [92]; Ovid wrote about beech, describing it as the primary source in the manufacture of plates and cups used in the rural houses of the time [73]. Beech was one of the most-used woods at Pompeii and Herculaneum [70,80], where it was also employed for the manufacture of bed legs [92]. Some fragments of beech wood interpreted as parts of a piece of furniture have been recovered from Roman Domus and farmhouses $[83,105,106]$. Components of Roman ships were made with beech wood $[67,69]$.

Wood charcoal samples of beech wood retrieved from Room E of the Domus of the Dolia could be interpreted as a part of a piece of furniture located in this room. Given the fragmentary nature of this charred wood, it is not possible to make any hypotheses concerning the typology of this furniture. However, given the characteristics of the wood, the context, and the parallels with the ancient literature and other archaeological realities, this hypothesis seems the most likely.

Wood charcoal fragments of maple wood (i.e., Acer sp.) were recovered from Room G of the Domus of the Dolia.

Maple wood has excellent mechanical characteristics; it is easy to work with, it is tenacious and elastic, and easily perishable $[40,107]$. Its fine texture is useful for turning works [40]. The Greek philosopher Theophrastus mentioned the use of this wood for yokes and bed nets [73]. According to Pliny, it was widely considered a suitable wood for making furniture, and was especially appreciated for tables $[73,91,104,108]$. The Roman poet Horace also praised the quality of this wood [104]. Charcoals and wood remains of maple wood were retrieved from Italian prehistoric archaeological sites $[57,58,109]$. For historical periods, we know of the use of this wood by the Egyptians, who particularly appreciated it for the manufacture of chariot frames [64]. Maple wood was widely used by Romans for the manufacture of tools as well as valuable objects, such as mirror frames and musical instruments, as is evidenced by several archaeological remains $[83,94,104,110,111]$. In the Roman empire, it was also largely used as furniture covering, thanks to the beauty of its wood [64]. During the medieval period it was employed for bowls, plates, knife handles and axes [55,112].

Despite the fragmentary composition of the samples collected from the corner Room G of the Domus of the Dolia, given the characteristics of this wood and the sampling place, a warehouse compartment, they were likely a part of the furniture or perhaps a tool present in the room.

Concerning the small number of fragments of maple wood sampled and identified at the Domus of the Dolia (Table 3), a plausible explanation is the characteristic of the easy perishability of this wood that would not have allowed for greater conservation. 
With regards to the $P$. cf. avium wood charcoal fragments retrieved from the Domus of the Dolia, they likely belong to cherry wood. Wood charcoals of this species were recovered from Rooms $\mathrm{G}$ and $\mathrm{H}$ of the Domus.

Cherry is a hard, strong, heavy and elastic wood [55,107]. It is a precious wood especially appreciated for its colour and the possibility of being finished [40]. This wood can be easily attacked by insects, so it is not a suitable wood to be used outdoors, and it must be previously treated [40]. It is mainly employed for furniture, musical instruments, cabinetmaking and turning $[40,107,113]$. It is excellent for engravings and carvings [55]. The use of cherry wood for the production of objects has been known since prehistoric times, as well as its wide use for the manufacture and covering of furniture during Roman times $[55,64,73]$. Charcoals and woods of this species have been retrieved at the Bronze Age settlements of Via Neruda (Florence, Italy) [57,58] and in the Roman Villa of Poppaea (Naples, Italy) [83].

Samples of cherry wood from Room G of the Domus of the Dolia were retrieved in a fragmentary state, making their interpretation arduous. However, their sampling from the interior of one of the Dolia present in the room seems to suggest a possible interpretation as parts of the lid of the Dolium. With respect to the single charred wooden element of cherry wood retrieved from Room H of the Domus, we must take into consideration that Room H was a semi-open compartment, and that cherry wood is not suitable to be used outdoors. Considering that this wooden element was sampled in-between Rooms H and G, we may suppose that it was likely part of the dividing door of these rooms. However, we cannot rule out the hypothesis that it could also be a piece of a furniture or a tool present in the room.

\subsection{Court Trees}

Concerning the charred wood fragments of Rosaceae recovered from Room $\mathrm{F}$ of the Domus of the Dolia, it was not possible to distinguish between the various species of this family at the micro-anatomical level. This family comprises many fruit tree species of the Mediterranean area, for instance apple, pear and plum trees. Considering the archaeological context, wood charcoal remains of Rosaceae are likely to belong to a fruit tree/s. Room F was an open courtyard, and the retrieved wood charcoal remains of fruit tree/s allows us to hypothesize about the existence of a garden inside the Domus. Rosaceae wood charcoal fragments were the only taxa present in this room, accounting for 3.19\% of the total wood charcoals identified (Table 3, Figure 6). This data seems to confirm the open-space nature of this room, in agreement with the archaeological data.

Regarding the small percentage of woods identified as possible court trees, this data can be explained by the burial conditions of these samples. Wooden remains of trees originally present in a garden-and therefore in an open-air space-have less chance of being preserved over time compared to wooden samples coming from a closed context.

\subsection{Exploitation of Different Local and Non-Local Tree Species and their Possible Supply Areas}

Everything seems to suggest that the wood choice was based on the characteristics of the woods, in order to employ them for different uses. However, cultural choices cannot be ruled out. The comparison of the identified tree species with the local vegetation (present and ancient) gave information regarding the employment of local and/or non-local species for the construction and furnishing of the Domus of the Dolia. The study shows, primarily, the employment of local tree species. The current vegetation of the Tuscan Maremma and its coastal hills, as well as the one where Vetulonia is located, is represented by sclerophyll and broad-leaved forests; there are holm oak woods with scrub and broad-leaved woods [114]. Regarding the species identified in this study, the three types of oak, $Q$. sect. robur, $Q$. sect. cerris and $Q$. sect. suber are considered local species, together with the tree species of $B$. sempervirens, Acer sp. and P. cf. avium [114,115]. This is confirmed by the results of pollen and charcoal analyses carried out in nearby areas of Vetulonia [10,14,15,17,116-124]. Many of these studies also revealed the strong impact made by the Etruscans on the Maremma 
environment, as evidenced by the strong exploitation of some local species, including oak wood, as indicated by the decrease in its pollen in the historical record $[10,14,17,122,123]$.

Concerning A. alba and F. sylvatica, indigenous populations of these two species currently naturally grow on the nearby Mount Amiata (approximately $60 \mathrm{~km}$ from Vetulonia) [125-127]. In this area, native fir populations are found at Pigellato (Piancastagnaio), Vivo d'Orcia and the Franciscan convent of the SS. Trinity of Santa Fiora [127]. The presence of silver fir wood on Mount Amiata in the past is proven by palynological data [128-131].

The possible supply of both species from Mount Amiata would therefore be supported by ecological data. There is also some historical evidence to support this hypothesis; Pope Pius II (1405-1464) employed the Amiata silver fir trees for the construction of his buildings in Pienza, and in his commentaries he wrote that the fir trees of Mount Amiata had also been used for the construction of ancient Roman buildings [132,133]. The supply of timber from this mountain appears to be confirmed by the ancient literary sources, which describe how the Romans usually obtained wood from this area of Etruria. The timber travelled on barges along the Ombrone and Albegna rivers, and, at the mouths of these rivers, port docks were placed; from there, the timber was transported to Rome [133,134]. The data from pollen and charcoal analyses $[135,136]$ seems to attest that silver fir would have grown at lower altitudes than the current ones throughout the Italian peninsula in the early Holocene. It would grow at low and medium altitudes in forest communities associated with deciduous species, mainly Quercus cerris, at least until the Middle Ages. This data was associated with a more extensive presence of this species in Italy. The decline of this species seems to have mainly been caused by climate change and human impact [135]. According to this data, some historical literary sources attested to the presence of fir trees at Mount Amiata during the Etruscan and Roman period at lower altitudes than they are currently found [133].

\subsection{Consideration of the Technological Data}

Regarding the tree ring observations and the anatomical alterations recorded, it was possible to reconstruct, at least in part, the technological data. In this sense, only a few possible considerations are reported, and they should not be considered conclusive.

Concerning the fragments interpreted as wooden roof framing elements, it was not possible to identify a curvilinear trend in the tree growth rings, and therefore the fragments analysed come from trunks. This observation corroborates the archaeological interpretation of these samples. With regard to the samples identified as deciduous oak wood, tyloses were almost always observed in the lumen of the spring wood vessels. This means that the innermost part of the trunk (the heartwood) was used.

Given the fragmentary nature of many of the wooden roof framing elements identified, we don't know the thickness of the sapwood, and therefore it is not possible to know the thickness of the trunks from which the wood samples were obtained. The presence of bark was not detected for any of the samples under study, and it was not possible to detect the diameter of the complete stem, nor the season of tree felling.

Concerning the conservation state of the wood, the analysis enabled the identification of galleries formed by xylophagous insects in numerous charred wood fragments of the silver fir wood, and a few in the deciduous and semideciduous oak wood. These channels indicate a partial degradation of some structural elements of the Domus before the starting of the fire.

Regarding the samples identified as furniture and furnishing elements, the analysis made it possible to verify their good conditions at the time of the fire, as for most of them no signs of deterioration by wood-decomposing organisms were detected. Some beech wood fragments, in which channels formed by lignivorous insects were detected, are an exception, which indicates their partial degradation before the advent of the fire, but beech wood is not considered to be a very durable wood [137]. 


\section{Conclusions}

The study of the Domus of the Dolia woods is particularly important considering that studies on this type of material of the Etruscan era are very rare throughout the Italian peninsula. This is the first study concerning the construction and furniture woods retrieved from an Etruscan residence of this type. The information obtained from the analyses provided knowledge about the type of residence and occupants of the Domus. Moreover, the study can indirectly provide access to the economical, technological, and social indicators of the Etruscan community of Vetulonia, and more generally of the Etruscan society.

The study of charred woods from the Domus of the Dolia revealed the use of different types of woods employed for the construction of the roof and the furnishing of the Domus. The great variety of woods and their differentiated uses offered great insight into the wood choices of the Domus builders. The type of building, the quality, and the attention employed in the choice of woods suggests that the residence was inhabited by wealthy occupants.

The results also allowed us to establish the utilization of local and non-local woods. Furthermore, the observation of the anatomical characteristics provided evidence of the conservation state of the woods before the advent of the fire.

If we consider that most of our knowledge concerning Etruscan society comes from the study of materials from funerary contexts, this study on materials which come from a very well-preserved Domus (unique throughout the Italian peninsula) is like a drop in a sea of what is still largely unknown. The excavation of the Domus of the Dolia is still underway, and future research lines foresee the study of charred woods retrieved in the other rooms (the northern part) of the Domus.

Author Contributions: Conceptualization, G.C.; methodology, G.C.; formal analysis, G.C.; investigation, G.C.; data curation, G.C., S.R., C.Q.; writing-original draft preparation, G.C.; writing-review and editing, G.C., M.B.; supervision, C.B.D., L.S. All authors have read and agreed to the published version of the manuscript.

Funding: This research has been developed thanks to the HERITAS Doctoral Program through a PhD grant (FCT (PD/BD/128278/2017) founded by the FCT—Fundação para a Ciência e a Tecnologia. The authors also acknowledge the Hercules Laboratory project (UIDB/04449/2020 e UIDP/04449/2020) founded by the FCT.

Institutional Review Board Statement: Not applicable.

Informed Consent Statement: Not applicable.

Data Availability Statement: Not applicable.

Acknowledgments: The first author is grateful to Rebecca Mac Roberts for the English revisions, comments and useful advice.

Conflicts of Interest: The authors declare no conflict of interest.

\section{References}

1. Cristofani, M. Gli Etruschi una Nuova Immagine; Giunti Editore: Firenze, Italy, 2000.

2. Cristofani, M.; Martelli, M. L'oro Degli Etruschi; De Agostini Editore: Novara, Italy, 1983.

3. Nestler, G.; Formigli, E. Granulazione Etrusca. Un'antica arte Orafa; Arti Grafiche Nencini: Poggibonsi, Siena, Italy, 2013.

4. Camporeale, G. I Commerci di Vetulonia in Età Orientalizzante; Sansoni Editore: Firenze, Italy, 1969.

5. Miller, P. A Study of Building Techniques and Materials from 800-500 BC; University of Edimburgh: Edinburgh, UK, 2015.

6. Amicone, S.; Croce, E.; Castellano, L.; Vezzoli, G. Building Forcello: Etruscan wattle-and-daub technique in the Po Plain (Bagnolo San Vito, Mantua, northern Italy). Archaeometry 2020, 62, 521-537. [CrossRef]

7. Ceccarelli, L.; Moletti, C.; Bellotto, M.; Dotelli, G.; Stoddart, S. Compositional characterization of Etruscan earthen architecture and ceramic production. Archaeometry 2020, 62, 1130-1144. [CrossRef]

8. Bound, M. The Giglio Wreck: A Wreck of the Archaic Period (C. 600 B.C.) off the Tuscan Island of Giglio: An Account of Its Discovery and Excavations: A Review of the Main Finds; Hellenic Institute of Marine Archaeology: Athens, Greece, 1991.

9. Coccolini, G.; Follieri, M. I legni dei pozzi del tempio A nel santuario etrusco di Pyrgi. Studi Etruschi 1980, 48, $277-291$. 
10. Mariotti Lippi, M.; Di Tommaso, P.L.; Giachi, G.; Mori Secci, M.; Paci, S. Archaeo-botanical investigations into an Etruscan farmhouse at Pian d'Alma (Grosseto, Italy). Atti Soc. Toscana Sci. Nat. Mem. Ser. B 2002, 109, 159-165.

11. Mariotti Lippi, M.; Mori Secci, M.; Giachi, G.; Bouby, L.; Terral, J.F.; Castiglioni, E.; Cottini, M.; Rottoli, M.; de Grummond, N.T. Plant remains in an Etruscan-Roman well at Cetamura del Chianti, Italy. Archaeol. Anthropol. Sci. 2020, 12. [CrossRef]

12. Marchesini, M.; Marvelli, S.; Gobbo, I.; Rizzoli, E. Paesaggio, ambiente e attivitaà antropica dalla Bologna villanoviana (VII-VI sec. a.C.) alla Bononia romana (I sec. d.C.) attraverso le analisi archeobotaniche. In Alla Ricerca di Bologna Antica e Medievale. Da Felsina a Bononia Negli Scavi di via D'Azeglio.; Curina, R., Malnati, L., Negrelli, C., Pini, L., Eds.; All'insegna del Giglio. Quaderni di Archeologia dell'Emilia Romagna 25: Firenze, Italy, 2010; pp. 145-162.

13. Rottoli, M. Analisi botaniche. In Tarquinia Etrusca, Una Nuova Storia, Catalogo della Mostra.; Moretti Sgubini, A.M., Ed.; L'Erma di Bretschneider: Rome, Italy, 2001; pp. 59-61.

14. Drescher Shneider, R.; De Beaulieu, J.L.; Magny, M.; Walter Simonnet, A.V.; Bossuet, G.; Millet, L. Vegetation history, climate and human impact over the last 15,000 years at Lago dell'Accesa (Tuscany, Central Italy). Veg. Hist. Archaeobot. 2007, 16, 279-299. [CrossRef]

15. Magny, M.; De Beaulieu, J.L.; Drescher-Schneider, R.; Vanniere, B.; Walter-Simonnet, A.V.; Miras, Y.; Millet, L.; Bossuet, G.; Peyron, O.; Brugiapaglia, E.; et al. Holocene climate changes in the central Mediterranean as recorded by lake-level fluctuations at Lake Accesa (Tuscany, Italy). Quat. Sci. Rev. 2007, 26, 1736-1758. [CrossRef]

16. Negri, G. Come si Possa Ricostruire la la Fisionomia Della Vegetazione Della Toscana Durante il Periodo Etrusco; Istituto Nazionale di Studi Etruschi ed Italici: Firenze, Italy, 1927; pp. 363-373.

17. Sadori, L.; Mercuri, A.M.; Lippi, M.M. Reconstructing past cultural landscape and human impact using pollen and plant macroremains. Plant Biosyst. 2010, 144, 940-951. [CrossRef]

18. Beltrame, M.; Coradeschi, G. Il progetto "Welcome Home". In Bentornati a Casa. La Domus dei Dolia di Vetulonia Riapre le Porte Dopo Duemila Anni. Catalogo Mostra (Vetulonia, Museo Civico Archeologico "Isidoro Falchi", 29 Luglio 2016-8 Novembre 2016; ARA Edizioni: Roma, Italy, 2016; p. 55.

19. Rafanelli, S.; Moita, P.; Mirão, J.; Carvalho, A.; Braga, P.; Vicente, R.; Galacho, C.; Dias, C.; Candeias, A.; Beltrame, M.; et al. Etruscan render mortars from Domus dei Dolia (Vetulonia, Italy). In Proceedings of the 3rd International Congress on Science and Technology for the Conservation of Cultural Heritage (TechnoHeritage 2017), Cadiz, Spain, 21-24 May 2017; Elsevier: Amsterdam, The Netherlands, 2017; p. 3.

20. Gregori, D. Una bottega vetuloniese di buccheri e di impasti orientalizzanti decorati a stampiglia. Stud. Mater. 1991, VI, 64.

21. Semplici, A. Il Museo Civico Archeologico Isidoro Falchi di Vetulonia; Effigi: Arcidosso, Italy, 2015.

22. Bruni, S. Un Medico al Servizio dell'Archeologia, un Protagonista della Ricerca Archeologica di Fine Ottocento; Bruni, S., Ed.; Forgotten Books: Campiglia, Italy, 1995.

23. Cygielman, M. Vetulonia Museo Civico Archeologico "Isidoro Falchi" Guida; Arti Grafiche Nencini: Firenze, Italy, 2002.

24. Falchi, I. Vetulonia e la Sua Necropoli Antichissima; Forgotten Books: Firenze, Italy, 1891.

25. Cygielman, M. Medea a Vetulonia. In Il Museo Civico Archeologico Isidoro Falchi di Vetulonia; Edizioni Quasar: Rome, Italy, 2015; p. 46.

26. Rondini, P.; Zamboni, L. Digging up excavations. Processi di ricontestualizzazione di "vecchi" scavi archeologici: Esperienze, problemi, prospettive. In Proceedings of the Atti del Seminario, Collegio Ghislieri, Pavia, Italy, 15-16 January 2015; Quasar: Rome, Italy, 2015.

27. Talocchini, A. Ultimi dati offerti dagli scavi vetuloniesi. Poggio Pelliccia-Costa Murata. In Proceedings of the L'Etruria Mineraria (Atti del XII Convegno di Studi Etruschi e Italici 16-20 Giugno 1979), Firenze, Italy, 16-20 June 1979; Neppi Modona, A., Ed.; Istituto Nazionale di Studi Etruschi ed Italici: Firenze, Italy, 1981; pp. 100-138.

28. Rafanelli, S. Le Mura di Vetulonia. In Il Museo Civico Archeologico Isidoro Falchi di Vetulonia; C\&P Adver Effigi: Arcidosso, Italy, 2015; pp. 20-21.

29. Agricoli, G.; Rafanelli, S.; Carnevali, S. Vetulonia. La Domus dei Dolia; Archeologi Effigi: Arcidosso, Italy, 2016.

30. Falchi, I. Vetulonia-Scavi Dell'anno 1894. I. Scoperta Degli Avanzi Della Città; Biblioteca Nazionale Braidense: Milan, Italy, 1895; pp. 272-317.

31. Falchi, I. Vetulonia-Nuove Scoperte Nell'area Della Città e Della Necropoli. Scavi del 1895 Nell'area Della Città; Biblioteca Nazionale Braidense: Milan, Italy, 1898; pp. 81-99.

32. Cygielman, M.; Agricoli, G.; Borgianni, R.; Rafanelli, S.; Spiganti, F.; Spiganti, S.; Trippetti, S.; Zoccoli, G. Castiglione della Pescaia (GR). Vetulonia. Poggiarello Renzetti. Not. Soprintend. Per I Beni Archeol. Toscana 2011, 5, 458-462.

33. De Benedetti, M. La moneta vetuloniese e la circolazione monetaria tra fine III e II sec. a.C. a Vetulonia. Nuovi dati dagli scavi di Poggiarello Renzetti (1985-1990). FOLDR FastiOnLine Doc. Res. 2013, 291, 1-12.

34. Rafanelli, S.; Spiganti, S. La città di Vetulonia in età ellenistica. Nuovi dati sul circuito murario urbano e sulla nuova Domus dei Dolia. In Proceedings of the Atti del VI Seminario Convengo, Palazzo Conti Gentili, Alatri, Italy, 28-29 November 2015; pp. 123-143.

35. Rafanelli, S.; Grassigli, G. Nuove scoperte nella città ellenistica di Vetulonia. In Nuove Scoperte Nella Città Ellenistica di Vetulonia; Edizioni Quasar: Roma, Italy, 2018; Volume XXV, pp. 525-559.

36. Fentress, E. The House of the Sicilian Greeks. In The Roman Villa: Villa Urbana.; Alfred, F., Ed.; University of Pennsylvenia Press: Philadelphia, PA, USA, 1999; pp. 29-42. 
37. Graham, J.W. Origins and interrelations of greek house and roman house. Phoenix 1966, 20, 3-31. [CrossRef]

38. Cambini, A. Contributi Scientifico-Pratici per una Migliore Conoscenza ed Utilizzazione del Legno; Grafiche Panetto e Petrelli: Spoleto, Italy, 1967.

39. Crivellaro, A.; Schweingruber, F.H. Atlas of Wood, Bark and Pith Anatomy of Eastern Mediterranean Trees and Shrubs; Haupt, P., Ed.; Springer: Berlin/Heidelberg, Germany, 2013; ISBN 978-3-642-37234-6.

40. Nardi Berti, R. La Struttura Anatomica del Legno ed il Riconoscimento dei Legnami Italiani di più Corrente Impiego (II Edizione); Berti, S., Fioravanti, M., Macchioni, N., Eds.; Ivalsa: Trentino Alto Adige, Italy, 2006.

41. Schweingruber, E.H. Anatomie Europäischer Hölzer. Anatomy of European Woods; Haupt, P., Ed.; Verlag Kessel: Stuttgart, Germany, 1990.

42. Castelletti, L. Legni e Carboni in Archeologia. In Scienze in Archeologia. II Ciclo di Lezioni Sulla Ricerca Applicata in Archeologia; All'Insegna del Giglio: Firenze, Italy, 1990; pp. 321-394.

43. Marguerie, D.; Hunot, J.Y. Charcoal analysis and dendrology: Data from archaeological sites in north-western France. J. Archaeol. Sci. 2007, 34, 1417-1433. [CrossRef]

44. Peña chocarro, L.; Peña Zapata, L.; González, U.J.E.; Ibáñez Estévez, J.J. Agricultura, alimentación y uso del combustible: Aplicación de modelos etnográficos en arqueobotánica botânica. Entorn-Estud. Patrim. Cult. Medi Ambi 2000, 3, 403-420.

45. Schweingruber, F.H.; Borner, A.; Schulze, E. Atlas of Woody Plant Stems: Evolution, Structure and Environmental Modifications; Springer: Berlin/Heildelberg, Germany, 2008.

46. Théry-Parisot, I.; Henry, A. Seasoned or green? Radial cracks analysis as a method for identifying the use of green wood as fuel in archaeological charcoal. J. Archaeol. Sci. 2012, 39, 381-388. [CrossRef]

47. Quézel, P.; Médail, F. Ecologie et Biogèographie des Forêts du Bassin Méditerrane; Elsevier: Paris, France, 2003.

48. Pearsall, D.M. Case Study in Paleoethnobotany. Understanding Ancient Lifeways trough the Study of Phytoliths, Starch, Macroremains, and Pollen; Routledge: New York, NY, USA, 2019.

49. Pielou, E.C. The Interpretation of Ecological Data: A Primer on Classification and Ordination; Wiley \& Sons: New York, NY, USA, 1984.

50. VanPool, T.L.; Robert, D.L. Quantitative Analysis in Archaeology; Sons, J.W., Ed.; Wile-Blackwell: New York, NY, USA, 2011.

51. Hubbard, R.N.L.B. Development of agriculture in Europe and the Near East: Evidence from quantitative studies. Econ. Bot. 1980, 34, 51-67. [CrossRef]

52. Moskal-del Hoyo, M. The ubiquity correction as an alternative method for the quantification of charcoal. Saguntum Papeles Del Lab. Arqueol. Val. 2011, 11, 35-36.

53. Giachi, G.; Mori Secci, M.; Pignatelli, O.; Gambogi, P.; Mariotti Lippi, M. The prehistoric pile-dwelling settlement of Stagno (Leghorn, Italy): Wood and food resource exploitation. J. Archaeol. Sci. 2010, 37, 1260-1268. [CrossRef]

54. Yegul, F.; Favro, D. Roman Achitecture and Urbanism. From the Origins to Late Antiquity; Cambridge University Press: Cambridge, UK, 2018; ISBN 9788578110796.

55. Gale, R.; Cluter, D. Plants in Archaeology: Identification Manual of Vegetative Plant Materials Used in Europe and the Southern Mediterranean to c. 1500; Westbury Publications, Royal Botanic Garden, KEW: Edinburgh, UK, 2000.

56. Bernabò Brea, M.; Cardarelli, A.; Cremaschi, M. Terramare. Cinque secoli di vita nella grande pianura. In Le Terramare. La più Antica Civiltà Padana; Electra: Milano, Italy, 1997; pp. 23-29.

57. Coradeschi, G.L. Insediamento Dell Antica età del Bronzo di Via Neruda a Sesto Fiorentino (FI): Lo Sfruttamento Delle Risorse Arboree; Universidade de Trás-os-Montes e Alto Douro: Vila Real, Portugal, 2012; pp. 1-143.

58. Coradeschi, G. O sítio da Idade do Bronze de Via Neruda em Sesto Fiorentino (Florença, Italy): Exploração dos recursos arbóreos. Techne 2013, 1, 61-66.

59. Celant, A. Ricerche Archeobotaniche Nell'area Romana. Ph.D. Thesis, Sapienza University, Rome, Italy, 1998.

60. Celant, A. Ricerche paleobotaniche nel sito eneolitico di Le Cerquete- Fianello (Maccarese, Fiumicino). In Le Dune, il Lago, il Mare. Una Comunità di Villaggio dell'età del Rame a Maccarese; Istituto Italiano di Preistoria e Protostoria: Firenze, Italy, 2002.

61. Corazza, S.; Castiglioni, E.; Rottoli, M.; Tasca, P.; Vitri, S. An Iron Age house at the border of the Veneti's Territory (Montereale Valcellina-Friuli Venezia Giulia-Italia). In Proceedings of the XIII U.I.S.P.P., Forlì, Italy, 8-14 September 1996; A.B.A.C.O.: Forlì, Italy, 1996; pp. 1393-1399.

62. Follieri, M.; Coccolini, A.; Catullo, A. Strutture lignee di un abitato dell'età del Bronzo nel lago di Mezzano (Viterbo). Ann. Bot. 1977, 36, 175-183.

63. Nisbet, R.; Rottoli, M. Le analisi dei macroresti vegetali dei siti dell'età del bronzo. In Le Terramare. La più Antica Civiltà Padana; Electra: Milano, Italy, 1997; pp. 469-474.

64. Caneva, G. La Biologia Vegetale per i Beni Culturali, Volume II: Conoscenza e Valorizzazione; Nardini Editore: Firenze, Italy, 2005.

65. Signorini, G.; Giulio, D.; Fioravanti, M.G. Il Legno Nei Beni Culturali-Guida alla Determinazione Delle Specie Legnose (Italian); Aguaplano Editore: Perugia, Italy, 2014.

66. Bernabei, M.; Bontadi, J.; Rea, R.; Büntgen, U.; Tegel, W. Dendrochronological evidence for long-distance timber trading in the Roman Empire. PLoS ONE 2019, 14, e0224077. [CrossRef] [PubMed]

67. Capretti, C.; Macchioni, N.; Pizzo, B.; Galotta, G.; Giachi, G.; Giampaola, D. The characterization of waterlogged archaeological wood: The three roman ships found in Naples (Italy). Archaeometry 2008, 50, 855-876. [CrossRef]

68. Ferrone, A.M.; Meucci, C. Prime osservazioni sulla barca di Ercolano: Il recupero e la costruzione navale. In Proceedings of the Il Restauro del Legno, Firenze, Italy, 8-11 November 1989; Messaggerie Toscane: Firenze, Italy, 1989; Volume I, pp. $105-112$. 
69. Giachi, G.; Lazzeri, S.; Lippi, M.M.; Macchioni, N.; Paci, S. The wood of "C" and "F" Roman ships found in the ancient harbour of Pisa (Tuscany, Italy): The utilisation of different timbers and the probable geographical area which supplied them. J. Cult. Herit. 2003, 4, 269-283. [CrossRef]

70. Moser, D.; Nelle, O.; Di Pasquale, G. Timber economy in the Roman Age: Charcoal data from the key site of Herculaneum (Naples, Italy). Archaeol. Anthropol. Sci. 2018, 10, 905-921. [CrossRef]

71. Giordano, G. Tecnologia del Legno: La Materia Prima; Unione Topografico-Editrice Torinese: Torino, Italy, 1981 ; Volume 1.

72. Gagarin, M. The Oxford Encyclopedia of Ancient Greece and Rome; Gagarin, M., Ed.; Oxford University Press: Oxford, UK, 2010; ISBN 9780195170726.

73. Ulrich, R.B. Roman Woodworkin; yale University Press: London, UK, 2007; ISBN 9788578110796.

74. Meiggs, R. Trees and Timber in the Ancient Mediterranean World; Oxford University Press: Oxford, UK, 1982.

75. Stellacci, S.; Rato, V. Timber-Framing Construction in Herculaneum Archaeological Site: Characterisation and Main Reasons for its Diffusion. Int. J. Archit. Herit. 2019, 1-19. [CrossRef]

76. Marzatico, F. L'architettura del legno negli abitati palafitticoli del Trentino. In Terramare. La Più Antica Civiltà Padana; Bernabò Brea, M., Cardarelli, A., Cremaschi, M., Eds.; Electra: Milano, Italy, 1997; pp. 263-271.

77. Albore Livadie, C.; Cicirelli, C.; Heussner, U.; Kastenmeier, P.; Pappalardo, M.T. Le analisi dendrocronologiche a Poggiomarino nel 2011-2012. Stud. Pompei 2012, XIX, 164-168.

78. Heussner, U. Cronologia assoluta della tarda Età del bronzo e della prima Età del Ferro a Longola/Poggiomarino. In Nuove Ricerche Archeologiche Nell'area Vesuviana (Scavi 2003-2006). Atti del Convegno Internazionale, Rome, Italy, 1-3 Febbraio 2007; Guzzo, P.G., Guidobaldi, M.P., Eds.; L'Erma di Bretschneider: Roma, Italy, 2008; pp. 489-491.

79. Di Pasquale, G.; Terzani, M. Archeobotanica a Populonia: Primi risultati e prospettive di ricerca. In Materiali per Populonia 5; Aprosio, S., Mascione, C., Eds.; ETS: Pisa, Italy, 2006; pp. 283-291.

80. Caramiello, R.; Fioravanti, M.; Griffa, A.; Macchioni, N.; Uzielli, L.; Zeme, A. Analisi e conservazione del materiale ligneo degli scavi di Ercolano: Problematiche e primi risultati. Allionia 1992, 31, 47-59.

81. Fioravanti, M.; Gallotta, G.P. I legni di più frequente impiego in epoca romana. In La Biologia Vegetale per i Beni Culturali, Vol 2. Conoscenza e Valorizzazione; Caneva, G., Ed.; Nardini: Firenze, Italy, 2005; pp. 22-25.

82. Moser, D.; Nelle, O.; Di Pasquale, G.; Di Pasquale, G. The Romans, the wood and the forest: State of the art and new data from the Vesuvius area (Naples, Italy). Saguntum Papeles del Lab. Arqueol. Val. 2011, 11, 113-114.

83. Moser, D.; Allevato, E.; Clarke, J.R.; Di Pasquale, G.; Nelle, O. Archaeobotany at Oplontis: Woody remains from the Roman Villa of Poppaea (Naples, Italy). Veg. Hist. Archaeobot. 2013, 22, 397-408. [CrossRef]

84. Allevato, E.; Di Pasquale, G. Archaeobotanical data from Vesuvius region in the Roman period: State of the art and perspective. In Studies on Vesuvius' North Slope and the Bay of Naples; De Simone, G.F., Ed.; Macfarlane RT: Jefferson, NC, USA, 2009 ; pp. $298-311$.

85. Allevato, E.; Buonincontri, M.; Vairo, M.; Pecci, A.; Cau, M.A.; Yoneda, M.; De Simone, G.F.; Aoyagi, M.A.; Angelelli, C.; Matsuyama, S.; et al. Persistence of the cultural landscape in Campania (Southern Italy) before the A.D. 472 Vesuvius eruption: Archaeoenvironmental data. J. Archaeol. Sci. 2012, 39, 399-406. [CrossRef]

86. Sadori, L.; Giardini, M.; Masi, A. Il paesaggio urbano e suburbano della Roma imperiale. Atti Soc. Dei Nat. Modena 2007, 138, 255-272.

87. Follieri, M. Resti vegetali macroscopici nel collettore ovest del Colosseo. Ann. Bot. 1975, 34, 123-141.

88. Allevato, E.; Russo Ermolli, E.; Boetto, G.; Di Pasquale, G. Pollen-wood analysis at the Neapolis harbour site (1st-3rd century AD, southern Italy) and its archaeobotanical implication. J. Archaeol. Sci. 2010, 37, 2365-2375. [CrossRef]

89. Begliuomini, V.; Benvenuti, M.; Mariotti Lippi, M.; Pallecchi, P.; Sagri, M. Il contesto paleoambientale dell'antico porto di Pisa. In Il Porto Urbano di Pisa Antica. La Fase Etrusca, il Contesto e il Relitto Ellenistico; Bruni, S., Ed.; Silvana Editoriale: Cinisello Balsamo, Italy, 2003; pp. 103-107.

90. Bertacchi, A.; Lombardi, T.; Sani, A.; Tomei, P.E. Plant macroremains from the Roman harbour of Pisa (Italy). Environ. Archaeol. 2008, 13, 181-188. [CrossRef]

91. Pliny. Naturalis Historiae.

92. Mols, S.T.A.M. Wooden Furniture in Herculaneum: Form, Technique and Function; BRILL: Leiden, The Netherlands, 1999.

93. Sherwood, A.N.; Nikolic, M.; Humphrey, J.W.; Oleson, J.P. Greek and Roman Technology a Sourced Book of Translated Greek and Roman Texts; Routledge: London, UK; New York, NY, USA, 2020.

94. Borghini, G.; Massafra, M.G. Legni da Ebanisteria; De Luca Editore D’Arte: Roma, Italy, 2002.

95. Nicholson, P.T.; Shaw, I. Ancient Egyptian Materials and Technology; Nicholson, P.T., Ian, S., Eds.; Cambridge University Press: Cambridge, UK, 2000.

96. Smith, W. A Dictionary of Greek and Roman Antiquities; Cambridge University Press: Cambridge, UK, 2013 ; ISBN 9781139794602.

97. Aranguren, B.; Revedin, A.; Amico, N.; Cavulli, F.; Giachi, G.; Grimaldi, S.; Macchioni, N.; Santaniello, F. Wooden tools and fire technology in the early neanderthal site of poggetti vecchi (Italy). Proc. Natl. Acad. Sci. USA 2018, 115, 2054-2059. [CrossRef]

98. Cunliffe, B.; Down, A.; Rudkin, D. Chichester Excavations IX: Excavations at Fishbourne 1969-88; Chichester District Council: Chichester, UK, 1996.

99. Pugsley, P. Roman Domestic Wood; Oxford University Press: Oxford, UK, 2003. 
100. Pulak, C. The Cargo of Uluburun Ship and Evidence for Trade with theAegean and Beyond. In Italy and Cyprus in Antiquity, 1500-450 BC: Proceedings of an International Symposium Held at the Italian Academy for Advanced Studies in America, 16-18 November 2000; Bonfante, L., Karageorghis, V., Eds.; Costakis and Leto Severis Foundation: Nicosia, Cyprus, 2001; pp. 13-60.

101. Simpson, E. Midas' Bed and a Royal Phrygian Burial. J. Field Archaeol. 1990, 17, 69-87.

102. Minor, D.; Schaeffer, G.C. New York American Railroad Journal and Advocate of Internal Improvements. July, 1833, January, 1834; Part II; Forgotten Books: London, UK, 2018.

103. Davies, N.; Jokiniemi, E. Dictionary of Architecture and Building Construction; Routledge: New York, NY, USA, 2008.

104. Pollen, J.H. Ancient and Modern Furniture and Woodwork; Committee of Council on Education: London, UK, 1875.

105. Giuliani, M.R.; Galotta, G.; Berardi, M.C.; Rapinesi, I.A. Alcuni casi studio su materiali tessili e lignei provenienti da scavo. In Scienza e Ricerca per i Beni Culturali. Microscopia Elettronica a Scansione e Microanalisi; Flavia, P., Ed.; Gangemi Editore: Rome, Italy, 2007; pp. 21-28.

106. Rattighieri, E.; Rinaldi, R.; Mercuri, A.M.; Bowes, K. Land use from seasonal archaeological sites: The archaeobotanical evidence of small roman farmhouses in Cinigiano, South-Eastern Tuscany-Central Italy. Ann. Bot. 2013, 3, 207-215. [CrossRef]

107. Abbate Edlmann, M.L.; Dell'Amico, P.; Giachi, G. Un relitto romano recuperato nelle acque dell'Isola del Giglio: La struttura navale e i legni impiegati per la sua realizzazione. In Il Restauro del Legno; Tampone, G., Ed.; Nardini Editore: Firenze, Italy, 1989; pp. 113-119.

108. Marvelli, S.; De'Siena, S.; Rizzoli, E.; Marchesini, M. The origin of grapevine cultivation in Italy: The archaeobotanical evidence. Ann. Bot. 2013, 3, 155-163. [CrossRef]

109. Corona, E.; D'Alessandro, R.; Follieri, M. I pali lignei dell'abitato Neolitico di Fimon-Molino Casarollo (Vicenza). Ann. Bot. 1974, XXXIII, 237-256.

110. Moreno-Larrazabal, A.; Urteaga, M.; Zapata, L.; Urteaga Artigas, M.; Zapata Peña, L. Identification of archaeological wood remains from the roman mine of Arditurri 3 (Oiartzun, Basque Country). Saguntum Papeles Lab. Arqueol. Val. 2011, 11, 159-160.

111. Veal, R.; Thompsn, G. Fuel Supplies for Pompeii Pre-Roman and Roman charcoals of the Casa delle Vestali. In Charcoals from the Past. Cultural and Palaeoenvironmental Implications: Proceedings of the Third International Meeting of Anthracology, Lecce, Italy, 31 June-1 July 2001; Fiorentino, G., Magri, D., Eds.; BAR International Series 1807; Archaeopress: Oxford, UK, 2008 ; p. 297.

112. Malmros, C. Wood Technology in the Viking Age Chamber Grave at Grimstrup, Jutland, Denmark. In Wood and Archaeology; Council of Europe: Strasbourg, France, 1988; p. 375.

113. Miller, P. The Gardners and Botanist's Dictionary; Library of New York: New York, NY, USA, 1807.

114. Regione, T. Piano Paesaggistico Regione Toscana. Scheda D'ambito 18 Maremma Grossetana; Regione Toscana: Firenze, Italy, 2015.

115. Selvi, F. A critical checklist of the vascular flora of Tuscan Maremma (Grosseto province, Italy). Flora Mediterr. 2010, $20,47-139$.

116. Bellotti, P.; Belluomini, G.; Bergamin, L.; Carboni, M.G.; Di Bella, L.; Improta, S.; Letuova, P.P.; Mandra, L.; Potyomkina, T.G.; Valeri, P.; et al. Nuovi dati cronostratigrafici sul sottosuolo della piana deltizia del Fiume Ombrone (Toscana Meridionale). Studi Costieri 2001, 4, 33-42.

117. Bellotti, P.; Caputo, C.; Davoli, L.; Evangelista, S.; Garzanti, E.; Pugliese, F.; Valeri, P. Morpho-sedimentary characteristics and Holocene evolution of the emergent part of the Ombrone River delta (southern Tuscany). Geomorphology 2004, 61, 71-91. [CrossRef]

118. Biserni, G.; Van Geel, B. Reconstruction of Holocene palaeoenvironment and sedimentation history of the Ombrone alluvial plain (South Tuscany, Italy). Rev. Palaeobot. Palynol. 2005, 136, 16-28. [CrossRef]

119. Buonincontri, M.; Allevato, E.; Di Pasquale, G. Vegetation history over the last 2500 years: A multi-site approach in Maremma (Tuscany, Italy). Saguntum Extra 2011, 11, 111-112.

120. Giachi, G.; Mariotti lippi, M.; Pallecchi, P. Indagini archeobotaniche. In Populonia. La Necropoli Delle Grotte. Lo Scavo Nell'area Della Cava (Pisa); Settesoldi, R., Ed.; ETS Editore: Pisa, Italy, 2009; pp. 335-344.

121. Giorgi, E.; Patera, A.; Zanini, E. L'insediamento romano e tardoantico del Vignale: Primi dati sulla campagna di scavo 2007. Not. Soprintend. Reg. Toscana 2008, 4, 374-378.

122. Mariotti lippi, M.; Giachi, G.; Paci, S.; Di Tommaso, P.L. Studi sulla vegetazione attuale e passata della Toscana meridionale (Follonica-Italia) e considerazioni sull'impatto ambientale dell'attivita metallurgica etrusca nel VI-V secolo a.C. Webbia J. Plant Taxon. Geogr. 2000, 55, 279-295.

123. Negri, M. Contributo alla conoscenza del lago dell'Accesa, Massa Marittima (Grosseto). Atti Mus. Stor. Nat. Maremma 1998, 17, 129-139.

124. Vannière, B.; Colombaroli, D.; Chapron, E.; Leroux, A.; Tinner, W.; Magny, M. Climate versus human-driven fire regimes in Mediterranean landscapes: The Holocene record of Lago dell'Accesa (Tuscany, Italy). Quat. Sci. Rev. 2008, 27, $1181-1196$. [CrossRef]

125. Gabellini, A.; Angiolini, C. La vegetazione. In Conservazione di Abies alba in Faggeta Abetina nel Pigelleto, Monte Amiata; Miozzo, M., Montini, P., Eds.; Regione Toscana: Firenze, Italy, 2007; pp. 48-67.

126. Papalini, O.; Miozzo, M. Distribuzione dei Nuclei di Abies Alba autoctoni di maggiori dimensioni. In Conservazione di Abies Alba in Faggeta Abetina nel Pigelleto, Monte Amiata; Miozzo, M., Montini, P., Eds.; Regione Toscana: Firenze, Italy, 2007 ; pp. 94-96.

127. Pecoraro, L. La popolazione di Abete bianco del Pigelleto, gli studi di genetica svolti. In Conservazione di Abies Alba in Faggeta Abetina nel Pigelleto, Monte Amiata; Miozzo, M., Montini, P., Eds.; Regione Toscana: Firenze, Italy, 2007; pp. 96-99.

128. Clerici, E. Sui resti di conifere del Monte Amiata. Soc. Geol. Ital. 1903, 22, 523-554. 
129. Tongiorgì, E. Ricerche Sulla Vegetazione Dell'etruria Marittima. G. Bot. Ital. 1938, 45, 388-390. [CrossRef]

130. Bertolani-Marchetti, D.; Jacopi, Z. Documenti palinologici del paesaggio forestale al Monte Amiata nei sedimenti del bacino lacustre delle Lame (Abbadia, S. Salvatore). Giorn. Bot. Ital. 1962, 69, 19-31. [CrossRef]

131. Bertolani Marchetti, D.; Soletti, G.A. La vegetazione del M. Amiata nell'ultimo interglaciale. Analisi polliniche nella farina fossile del giacimento di Fontespilli. Stud. Trentini Sci. Nat. 2007, 49, 159-177.

132. Repetti, E. Dizionario Geografico Fisico Storico Della Toscana (Firenze); Firenze Libri: Firenze, Italy, 2005.

133. Vanni, E. Le Culture dell'Ambiente, del Territorio e dei Paesaggi. Ph.D. Thesis, University of Foggia, Foggia, Italy, 2014.

134. Ciampoltrini, G. Albinia, Fluvius habet positionem. Scavi 1983-1988 nell'approdo alla foce dell'Albegna (Orbetello-Gr). Rass. Archeol. 1997, 14, 253-295.

135. Di Pasquale, G.; Allevato, E.; Cocchiararo, A.; Moser, D.; Pacciarelli, M.; Saracino, A. Late Holocene persistence of Abies alba in low-mid altitude deciduous forests of central and southern Italy: Newperspectives fromcharcoal data. J. Veg. Sci. 2014, 25, 1299-1310. [CrossRef]

136. Tinner, W.; Colombaroli, D.; Heiri, O.; Henne, P.D.; Steinacher, M.; Untenecker, J.; Vescovi, E.; Allen, J.R.M.; Carraro, G.; Valsecchi, $\mathrm{V}$. he past ecology of Abies alba provides new perspectives on future responses of silver fir forests to global warming. Ecol. Monogr. 2013, 83, 419-439. [CrossRef]

137. Ruffinatto, F.; Cremonini, C.; Zanuttini, R. Atlante dei Principali Legni Presenti in Italia; Regione Piemonte-Direzione Opere Pubbliche-Settore Forestale: Torino, Itlay, 2019; p. 106, ISBN 9788896046067. 